\title{
SOA formation from the photooxidation of $\alpha$-pinene: systematic exploration of the simulation of chamber data
}

\author{
Renee C. McVay ${ }^{1}$, Xuan Zhang ${ }^{2, a}$, Bernard Aumont ${ }^{3}$, Richard Valorso $^{3}$, Marie Camredon ${ }^{3}$, Yuyi S. La ${ }^{3}$, \\ Paul O. Wennberg ${ }^{2,4}$, and John H. Seinfeld ${ }^{1,2}$ \\ ${ }^{1}$ Division of Chemistry and Chemical Engineering, California Institute of Technology, Pasadena, CA 91125, USA \\ ${ }^{2}$ Division of Engineering and Applied Science, California Institute of Technology, Pasadena, CA 91125, USA \\ ${ }^{3}$ LISA, UMR CNRS/INSU 7583, Université Paris Est Créteil et Université Paris Diderot, Institut Pierre Simon Laplace, \\ 94010 Créteil CEDEX, France \\ ${ }^{4}$ Division of Geological and Planetary Sciences, California Institute of Technology, Pasadena, CA 91125, USA \\ anow at: Center for Aerosol and Cloud Chemistry, Aerodyne Research, Billerica, MA, USA \\ Correspondence to: John H. Seinfeld (seinfeld@caltech.edu)
}

Received: 2 November 2015 - Published in Atmos. Chem. Phys. Discuss.: 25 November 2015

Revised: 17 February 2016 - Accepted: 23 February 2016 - Published: 4 March 2016

\begin{abstract}
Chemical mechanisms play an important role in simulating the atmospheric chemistry of volatile organic compound oxidation. Comparison of mechanism simulations with laboratory chamber data tests our level of understanding of the prevailing chemistry as well as the dynamic processes occurring in the chamber itself. $\alpha$-Pinene photooxidation is a well-studied system experimentally, for which detailed chemical mechanisms have been formulated. Here, we present the results of simulating low-NO $\alpha$-pinene photooxidation experiments conducted in the Caltech chamber with the Generator for Explicit Chemistry and Kinetics of Organics in the Atmosphere (GECKO-A) under varying concentrations of seed particles and $\mathrm{OH}$ levels. Unexpectedly, experiments conducted at low and high $\mathrm{OH}$ levels yield the same secondary organic aerosol (SOA) growth, whereas GECKO-A predicts greater SOA growth under high OH levels. SOA formation in the chamber is a result of a competition among the rates of gas-phase oxidation to low-volatility products, wall deposition of these products, and condensation into the aerosol phase. Various processes - such as photolysis of condensed-phase products, particle-phase dimerization, and peroxy radical autoxidation - are explored to rationalize the observations. In order to explain the observed similar SOA growth at different $\mathrm{OH}$ levels, we conclude that vapor wall loss in the Caltech chamber is likely of order $10^{-5} \mathrm{~s}^{-1}$, consistent with previous experimental measurements in that chamber. We find that GECKO-A tends to over-
\end{abstract}

predict the contribution to SOA of later-generation oxidation products under high-OH conditions. Moreover, we propose that autoxidation may alternatively resolve some or all of the measurement-model discrepancy, but this hypothesis cannot be confirmed until more explicit mechanisms are established for $\alpha$-pinene autoxidation. The key role of the interplay among oxidation rate, product volatility, and vapor-wall deposition in chamber experiments is illustrated.

\section{Introduction}

Secondary organic aerosol (SOA) contributes substantially to the tropospheric particle mass loading (Jimenez et al., 2009), which in turns influences visibility, direct radiative forcing, cloud formation, and human health (Hallquist et al., 2009). Monoterpenes contribute significantly to global SOA formation, with an estimated emission rate of $100-130 \mathrm{Tg} \mathrm{Cyr}^{-1}$ and SOA mass yield of 10-20\% (Hoffmann et al., 1997; Pye et al., 2010; Guenther et al., 1995). Of the terpenes, $\alpha$-pinene has the highest estimated emission rate of $34 \mathrm{Tg} \mathrm{Cyr}^{-1}$ (Pye et al., 2010). Numerous studies have examined SOA formation from both the $\mathrm{OH}$ oxidation and ozonolysis of $\alpha$-pinene (Hoffmann et al., 1997; Griffin et al., 1999; Kamens and Jaoui, 2001; Takekawa et al., 2003; Presto et al., 2005a, b; $\mathrm{Ng}$ et al., 2006; Pathak et al., 2007; Shilling et al., 2008; Ng et al., 2007a; Eddingsaas et al., 2012b). Ozonolysis is a more 
efficient route to $\alpha$-pinene SOA than OH oxidation (Griffin et al., 1999), and the ozonolysis path has received considerable attention. Fewer studies have examined SOA formation from $\mathrm{OH}$ oxidation of $\alpha$-pinene, and even fewer studies have focused on low-NO conditions, under which most $\alpha$-pinene is oxidized (Nozière et al., 1999; Ng et al., 2007a; Claeys et al., 2009; Eddingsaas et al., 2012a). However, nearly half of the global sink of $\alpha$-pinene has been estimated to be reaction with $\mathrm{OH}(42 \%)$; the remainder is oxidized predominantly by $\mathrm{O}_{3}$, with only $12 \%$ oxidized by $\mathrm{NO}_{3}$ (Capouet et al., 2008).

As in virtually all volatile organic compound (VOC) systems that lead to SOA, the $\mathrm{OH}$ oxidation of $\alpha$-pinene is complex, and parts of the mechanism are still not fully characterized (Peeters et al., 2001; Vereecken et al., 2007; Eddingsaas et al., 2012a, b). Theoretical and experimental work has indicated that heretofore unidentified alkoxy and peroxy isomerization channels may contribute substantially to SOA formation (Peeters et al., 2001; Capouet et al., 2004; Vereecken et al., 2007; Ehn et al., 2014; Rissanen et al., 2014). Further evidence suggests that particle-phase dimerization reactions are also important to SOA growth in the $\alpha$-pinene system, although most studies have focused on the ozonolysis path (Gao et al., 2004a, b; Lopez-Hilfiker et al., 2015). Condensed-phase photolysis has also been shown to affect SOA formation from $\alpha$-pinene, although again the focus has been predominantly on SOA produced via ozonolysis (Henry and Donahue, 2012; Donahue et al., 2012; Epstein et al., 2014; Wong et al., 2015). Uncertainty in the mechanism of SOA formation by photooxidation leads to uncertainty in global predictions of $\alpha$-pinene SOA (Pye et al., 2010).

Experiments in environmental chambers produce the basic data on the extent of SOA formation from volatile organic compounds and provide a means to test our understanding of the underlying chemistry of SOA formation. Simulations with explicit chemical mechanisms provide a means to evaluate predictions of SOA formation using chamber observations made under a variety of conditions (Capouet et al., 2008; Valorso et al., 2011). The goal of the present work is to carry out such an evaluation for the $\alpha$-pinene $\mathrm{OH}$ photooxidation system.

\section{$2 \alpha$-Pinene photooxidation mechanism}

\subsection{Gas-phase oxidation}

A near-explicit gas-phase oxidation mechanism for the oxidation of $\alpha$-pinene was generated using the Generator for Explicit Chemistry and Kinetics of Organics in the Atmosphere (GECKO-A) (Aumont et al., 2005; Camredon et al., 2007). GECKO-A automatically assigns reactions and rate constants on the basis of experimental data and structureactivity relationships (SARs), producing chemical mechanisms far more detailed and explicit than can be written manually (Aumont et al., 2005). As described in Valorso et al.
(2011), a protocol is implemented in GECKO-A to reduce the number of species generated to meet computational limits while maintaining as much chemical detail as possible; for example, gas-phase chemistry is not generated for species with vapor pressures below $10^{-13} \mathrm{~atm}$, and isomer substitution is allowed for position isomers for non-radical species formed with a maximum yield less than $2 \%$ after two or more generations. Vapor pressures are estimated using the Nannoolal et al. (2008) method. Four generations of oxidation of $\alpha$-pinene in GECKO-A (a generation encompassing reaction with an oxidant such as $\mathrm{OH}$ up to the formation of a stable product) yield $9 \times 10^{5}$ reactions and $1.8 \times 10^{5}$ species. SOA predictions for the base case are found not to be sensitive to the number of generations beyond three (sensitivity tests not shown).

$\mathrm{OH}$ oxidation of $\alpha$-pinene proceeds predominantly via $\mathrm{OH}$ addition, with minor channels proceeding via hydrogen abstraction. An overview of the base mechanism in GECKOA for the $\mathrm{OH}$ oxidation of $\alpha$-pinene is shown in black in Fig. 1 and discussed in more detail in Valorso et al. (2011). Updates to this mechanism (shown in blue in Fig. 1) were added here based on recent literature. Vereecken et al. (2007) proposed several non-traditional pathways in the $\mathrm{OH}$ oxidation of $\alpha$-pinene based on quantum and theoretical chemical calculations. Species in Fig. 1 are labeled to be consistent with Vereecken et al. (2007). Species R1 is formed with $22 \%$ yield by a prompt ring opening of the four-membered ring following initial $\mathrm{OH}$ addition to the double bond in $\alpha$ pinene (Peeters et al., 2001). A 40:60 ratio of syn vs. anti stereochemistry is estimated for species R1 (Vereecken et al., 2007). The anti conformer is predicted to undergo a 1,6hydrogen shift to form a peroxide, forming a radical stabilized by allyl resonance, R7. This reaction is predicted to dominate over all other peroxy reactions for the anti conformer even in high-NO conditions. The position of oxygen addition to the alkyl radical R7 is not well constrained. The branching ratio between addition at the secondary and tertiary sites has conservatively been predicted to be 50:50 (Vereecken et al., 2007). Vereecken et al. (2007) calculate that the syn conformer of R1 will not only participate in traditional peroxy chemistry but will also undergo ring closure to form a six-membered ring, species R3. Vereecken et al. (2007) calculate a rate constant for this reaction of $2.6 \mathrm{~s}^{-1}$ at 298 K. Species R2 in Fig. 1, formed from the reaction of the syn conformer of species $\mathrm{R} 1$ with $\mathrm{NO}$ and $\mathrm{RO}_{2}$, is predicted to undergo a ring-closure reaction to form species R10. This reaction is predicted to dominate over acetone elimination and hydroxy formation, the previous pathways for R2 in GECKO-A (Valorso et al., 2011). R10 adds oxygen and then participates in the usual peroxy reactions.

The $\mathrm{HO}_{2}$ chemistry has also been updated in GECKO-A. The main reaction channel for reaction of alkyl peroxy radicals with $\mathrm{HO}_{2}$ is formation of hydroperoxides. Recent evidence indicates that the reaction of some peroxy radicals with $\mathrm{HO}_{2}$ can also lead to an alkoxy radical, regenerating 


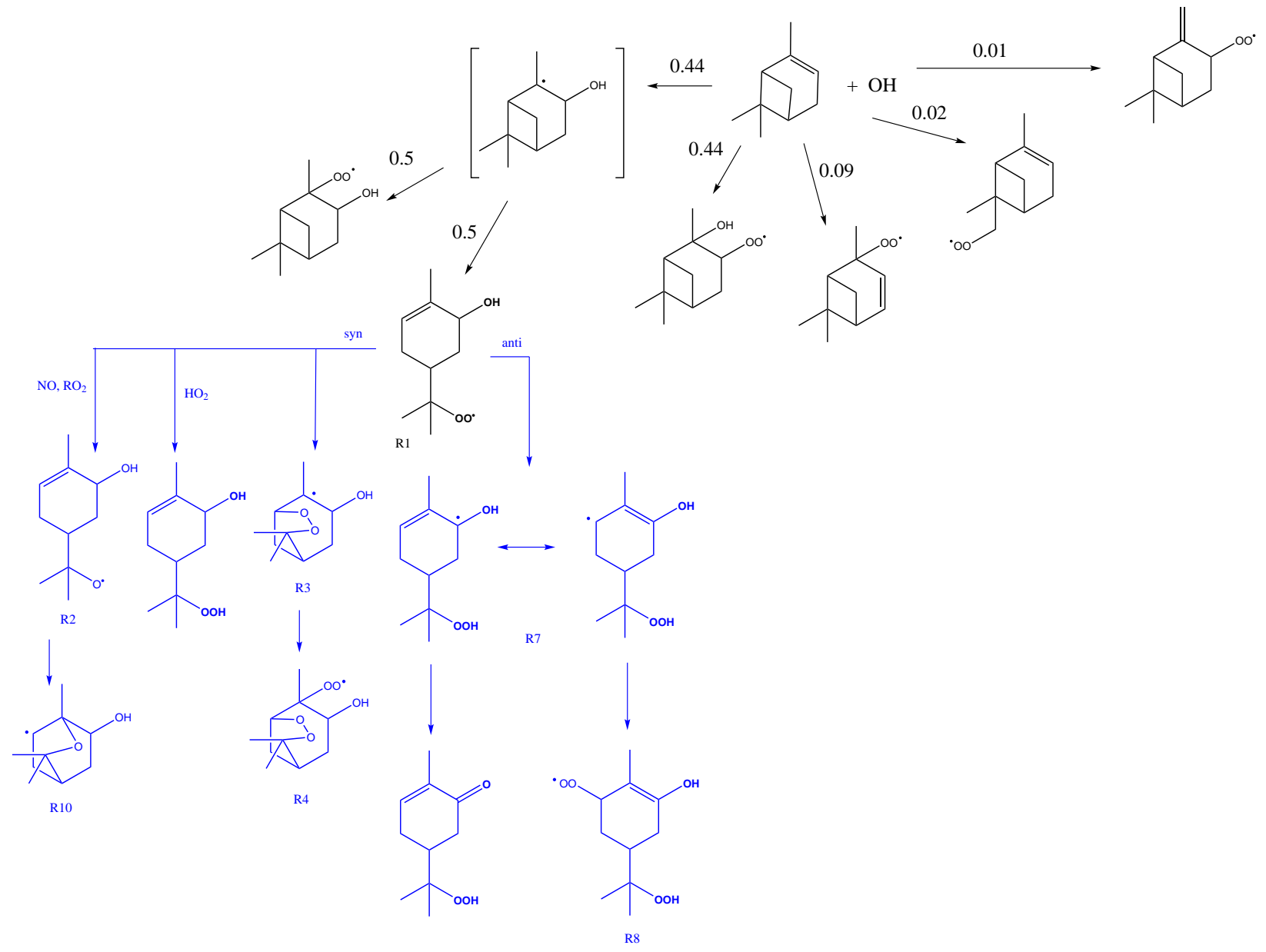

Figure 1. Overview of the $\alpha$-pinene $+\mathrm{OH}$ oxidation mechanism in GECKO-A. Reactions in black are those originally implemented in Valorso et al. (2011). Additions to this mechanism are shown in blue. Species are labeled to be consistent with Vereecken et al. (2007). All subsequent chemistry is generated in GECKO-A according to the standard protocols in GECKO-A.

OH (Hasson et al., 2004; Dillon and Crowley, 2008; Birdsall et al., 2010; Eddingsaas et al., 2012a). This reaction is promoted by the presence of neighboring polar functional groups, which can stabilize the intermediate leading to the alkoxy through hydrogen bonding (Hasson et al., 2005). This pathway has been added to GECKO-A for molecules with an oxygenated moiety in the $\alpha$ position to the peroxy radical. Estimates of the yield of the alkoxy for small acyl peroxy radicals range from 0.15 to 0.7 (Hasson et al., 2004; Dillon and Crowley, 2008); however, branching ratios for the larger molecules in the $\alpha$-pinene mechanism have not been determined. In light of this uncertainty, the branching ratio between the hydroperoxide and the alkoxy has been assigned to $80: 20$ in GECKO-A.

Ozonolysis chemistry in GECKO-A does not explicitly include the Criegee biradicals formed from the addition of $\mathrm{O}_{3}$ to the $\alpha$-pinene double bond; rather the predicted products of the Criegee intermediates are directly assigned to the $\alpha$-pinene ozonolysis reaction. This simplification over- looks potential reactions of the stabilized Criegee intermediates (SCIs) with water, alcohols, acids, carbonyls, etc. (Ma et al., 2008; Tobias and Ziemann, 2001). Reaction of SCIs with water to form pinonaldehyde is thought to be significant (Capouet et al., 2008), and a direct route to pinonaldehyde has been added in GECKO-A. The initial reaction step for ozonolysis is shown in Fig. S1 in the Supplement. Furthermore, Ma et al. (2008) proposed several later-generation intramolecular isomerization reactions to form low-volatility acids. These reactions have been implemented in GECKOA as a sensitivity test. Virtually no change in predicted SOA concentrations is observed when adding these reactions or when changing the branching ratios of the SCI products. Separate (not shown), purely ozonolysis simulations showed very little SOA formation, indicating potential missing pathways in the ozonolysis mechanism forming low-volatility products. Updating the ozonolysis mechanism should be the subject of future studies. The above updates constitute the 
base mechanism. Sensitivity tests applied on this base mechanism are addressed in the sections that follow.

\subsection{Condensed-phase photolysis}

Photolysis of gas-phase compounds containing carbonyl, peroxide, or nitrate chromophores is included automatically within oxidation schemes generated by GECKO-A (Aumont et al., 2005). For the simulations presented here, compoundspecific photolysis rates are calculated using cross sections and quantum yields described in Aumont et al. (2005) and measured irradiance data in the Caltech chamber. Photolysis of condensed-phase compounds, recently shown to lead to rapid loss of $\alpha$-pinene SOA (Henry and Donahue, 2012; Donahue et al., 2012; Epstein et al., 2014; Wong et al., 2015), is included here as a possible reaction route. Because GECKO-A does not generate chemical reactions within the condensed phase, radical species produced by condensedphase photolytic reactions are assumed to be irreversibly lost and to not participate in subsequent chemistry (Hodzic et al., 2015). This approximation likely represents an upper limit to the actual physical process since it does not account for recombination of fragments in the particle phase (Henry and Donahue, 2012; Hodzic et al., 2015). Two methods of calculating condensed-phase photolysis rate constants were tested in Hodzic et al. (2015): (1) all photolabile compounds in the condensed phase are assigned the same empirically derived rate constant, and (2) the condensed-phase photolytic rate constant for each species is set to the corresponding gasphase value. Hodzic et al. (2015) showed that the second method generally results in a greater loss of SOA. Therefore, assumption (2) is tested in the present simulations to evaluate the maximum possible impact of condensed-phase photolysis on overall SOA growth.

\subsection{Particle-phase dimerization}

The importance of aerosol-phase dimerization and oligomerization reactions has been demonstrated (Kalberer et al., 2004; Gao et al., 2004a, b; Tolocka et al., 2004; Yee et al., 2013; Shiraiwa et al., 2013; Fahnestock et al., 2014). These include alcohol + carbonyl to form hemiacetals and acetals, hydroperoxide + carbonyl to form peroxyhemiacetals and peroxyacetals, carboxylic acid + alcohol to form esters, and aldehyde self-reactions to form aldols (Ziemann and Atkinson, 2012). Shiraiwa et al. (2013) modeled a generalized particle-phase reaction of an SVOC + carbonyl with a rate constant of $12 \mathrm{M}^{-1} \mathrm{~s}^{-1}$ when fitting the observed evolution of the particle size distribution of dodecane SOA. In contrast, Capouet et al. (2008) modeled the formation of peroxyhemiacetals during $\alpha$-pinene SOA formation using a rate constant of $0.06 \mathrm{M}^{-1} \mathrm{~s}^{-1}$; they found that these reactions had a minor impact on SOA yield, except during ozonolysis with large $\mathrm{VOC} / \mathrm{NO}_{x}$ ratios that led to high hydroperoxide yields.
In the present work, particle-phase dimerization reactions have been added to the GECKO-A $\alpha$-pinene oxidation scheme for aldehydes, hydroperoxides, alcohols, and carboxylic acids. Three reaction pairings are considered: aldehyde + alcohol, aldehyde + hydroperoxide, and carboxylic acid + alcohol. As a first approximation, reactions are assumed to be irreversible and to form nonvolatile products. The mass of dimers becomes part of the organic aerosol mass into which gas-phase species can partition. The rate constant is set to be the same for each dimerization reaction, and two values are tested: $12 \mathrm{M}^{-1} \mathrm{~s}^{-1}$ (Shiraiwa et al., 2013) and $0.01 \mathrm{M}^{-1} \mathrm{~s}^{-1}$ (Ziemann and Atkinson, 2012). The rate constant is converted from liters of solution to volume of chamber air based on the amount of organic aerosol condensed at each time step.

\section{Box model for SOA formation}

Each $\alpha$-pinene oxidation scheme generated for the different sensitivity tests is coupled to a box model describing the chemical dynamics within the chamber, including dynamic transport of vapors to the particle phase and to the chamber walls.

\subsection{Vapor-particle transport}

In previous versions of GECKO-A, instantaneous equilibrium partitioning is assumed to occur between the vapor and particle phases (Camredon et al., 2007; Lee-Taylor et al., 2015). As a more general treatment of vapor-particle transport, dynamic partitioning for mass transfer between the gas and the particle phase is implemented here as described in La et al. (2016), with a few modifications. Mass transfer to and from the particle is represented by

$$
\begin{aligned}
& \left(\frac{\mathrm{d} G_{i}}{\mathrm{~d} t}\right)_{\mathrm{gp}}=-k_{\mathrm{gp}} G_{i}+k_{\mathrm{pg}} P_{i}, \\
& \left(\frac{\mathrm{d} P_{i}}{\mathrm{~d} t}\right)_{\mathrm{pg}}=k_{\mathrm{gp}} G_{i}-k_{\mathrm{pg}} P_{i},
\end{aligned}
$$

where $k_{\mathrm{gp}}$ and $k_{\mathrm{pg}}$ are first-order rate constants for transport to and from the particle $\left(\mathrm{s}^{-1}\right)$, and $G_{i}$ and $P_{i}$ are concentrations in the gas and particle phase, respectively. Mass transfer can be limited by gas-phase diffusion, interfacial accommodation, or particle-phase diffusion (e.g., Mai et al., 2015). Particle-phase diffusion in GECKO-A is assumed to be sufficiently rapid that particles are well mixed. Recent studies have shown that the assumption of rapid particle-phase diffusion in SOA may not be accurate owing to semi-solid behavior (Perraud et al., 2012; Cappa and Wilson, 2011; Vaden et al., 2010, 2013; Virtanen et al., 2010, 2011; Kuwata and Martin, 2012; Saukko et al., 2012; Abramson et al., 2013; Renbaum-Wolff et al., 2013). Computationally, the gas-particle accommodation coefficient, $\alpha_{\mathrm{p}}$, is used to approximate resistances to gas-particle partitioning from sur- 
face accommodation and particle-phase diffusion (Saleh et al., 2013). Therefore, the overall rate constant of mass transfer $k_{\mathrm{gp}}$ can be approximated as

$\frac{1}{k_{\mathrm{gp}}}=\frac{1}{k_{\mathrm{diff}}}+\frac{1}{k_{\mathrm{int}}}$

with $k_{\text {diff }}=4 \pi D_{\mathrm{g}} r_{\mathrm{p}} C_{\mathrm{p}}$ and $k_{\text {int }}=\alpha_{\mathrm{p}} \bar{c} \pi r_{\mathrm{p}}^{2} C_{\mathrm{p}}$, where $D_{\mathrm{g}}$ is the species gas-phase diffusivity, $r_{\mathrm{p}}$ is the particle radius, $C_{\mathrm{p}}$ is the number of particles per unit volume of air, $\alpha_{\mathrm{p}}$ is the gas-particle accommodation coefficient, and $\bar{c}$ is the gas-phase mean velocity (Seinfeld and Pandis, 2006). In the present work, the accommodation coefficient $\alpha_{\mathrm{p}}$ is treated as a parameter that can be varied in order to produce the best fit to the observed SOA growth. In the model, a single particle size bin is used, so that all particles have the same radius. For all experiments except nucleation, the initial inorganic seed radius is set at $50 \mathrm{~nm}$, and the initial number concentration is calculated from the measured initial seed surface area. GECKO-A does not currently include a mechanism for nucleation; therefore, for the nucleation experiment, an initial seed concentration of $10^{4} \mathrm{~cm}^{-3}$ was assumed with an initial radius of $5 \mathrm{~nm}$. The number concentration of particles $C_{\mathrm{p}}$ in the model remains unchanged over the course of the experiment as $r_{\mathrm{p}}$ grows owing to condensation of organic aerosol. Particle wall loss is not included in GECKO-A. SOA growth in the $\alpha$-pinene system is essentially independent of seed surface area (discussed in the Results section); therefore, lack of particle wall loss in GECKO-A will not substantially affect SOA predictions. $r_{\mathrm{p}}$ is calculated at each time step as

$r_{\mathrm{p}}=\left(\frac{3}{4 \pi}\left(\frac{4}{3} \pi r_{\mathrm{p} 0}^{3}+\frac{M_{\mathrm{aer}} C_{\mathrm{aer}}}{N_{A} \rho_{\mathrm{OA}} C_{\mathrm{p}}}\right)\right)^{\frac{1}{3}}$,

where $r_{\mathrm{p} 0}$ is the initial inorganic seed radius, $M_{\mathrm{aer}}$ is the organic aerosol mean molecular weight, $C_{\mathrm{aer}}$ is the organic aerosol mass concentration $\left(\right.$ molec $\mathrm{cm}^{-3}$ ), and $\rho_{\mathrm{OA}}$ is the organic aerosol density $\left(1.32 \mathrm{~g} \mathrm{~cm}^{-3}\right.$ for $\alpha$-pinene SOA; $\mathrm{Ng}$ et al., 2007a). Condensation to and evaporation from the particle occurs until equilibrium is reached between the gas and particle phases (if ever). The gas-particle partitioning at equilibrium is assumed to follow Raoult's law; therefore the reverse rate constant for mass transfer from the particle to the gas phase is calculated from the relationship (La et al., 2016)

$\frac{k_{\mathrm{gp}}}{k_{\mathrm{pg}}}=\frac{R T}{P^{\text {vap }}} \frac{C_{\mathrm{aer}}}{M_{\mathrm{aer}} \gamma_{\mathrm{aer}}}$,

where $R$ is the ideal gas constant, $T$ is the temperature, $P^{\text {vap }}$ is the species vapor pressure, and $\gamma_{\text {aer }}$ is the activity coefficient in the particle phase (assumed to be 1).

\subsection{Vapor-wall transport}

Chamber data are affected by wall deposition of semi and low-volatility vapors (Loza et al., 2010; Matsunaga and Ziemann, 2010; Kokkola et al., 2014; Yeh and Ziemann, 2014,
2015; Zhang et al., 2014, 2015; Bian et al., 2015). Partitioning of vapor species between the gas phase and the chamber wall is based on the parameterization of Matsunaga and Ziemann (2010) and is implemented as described in La et al. (2016), with minor variations. Reported values for the rate of transport from the gas to the wall, $k_{\mathrm{gw}}$, span several orders of magnitude in different chambers (Matsunaga and Ziemann, 2010; Zhang et al., 2014, 2015; Loza et al., 2010, 2014). Wall loss rates directly measured in the Caltech chamber are of order $10^{-5}-10^{-6} \mathrm{~s}^{-1}$ (Zhang et al., 2015; Loza et al., 2010, 2014), although Zhang et al. (2014) fit a wall loss rate of $10^{-4} \mathrm{~s}^{-1}$ during toluene SOA experiments. Gaswall equilibration timescales, $\tau_{\mathrm{g}, \mathrm{w}}$, of order $10-100 \mathrm{~min}$ have consistently been measured in the $8.2 \mathrm{~m}^{3}$ chamber used by Yeh and Ziemann (2015). With $\tau_{\mathrm{g}, \mathrm{w}}=1 /\left(k_{\mathrm{gw}}+k_{\mathrm{wg}}\right)$ (La et al., 2016), these timescales correspond to wall loss rates of $10^{-3}-10^{-4} \mathrm{~s}^{-1}$. The Yeh and Ziemann (2015) chamber is smaller than the Caltech chamber, 8.2 vs. $24 \mathrm{~m}^{3}$; however, the differences in measured wall loss rates are greater than expected if wall loss scales with the surface-to-volume ratio of the chamber. It has been suggested that rapid initial vapor wall loss could be difficult to distinguish from changes in concentration due to injection and mixing during the long fill period in the Caltech chamber (Zhang et al., 2014; Loza et al., 2014). Vapor species could potentially rapidly equilibrate with the wall and be subsequently lost to the wall with a much slower uptake owing to relaxation of the Teflon polymer (Yeh and Ziemann, 2015). Sensitivity tests in the present work examine the extent to which these differences indicate significantly slower vapor wall loss in the Caltech chamber or arise from the procedure by which experimental measurements were carried out. Furthermore, Zhang et al. (2015) showed that $k_{\mathrm{gw}}$ may depend on the species' volatility; here we assume $k_{\mathrm{gw}}$ to be the same for all species in order to evaluate the order of magnitude of $k_{\mathrm{gw}}$ needed to fit the observations. The nominal value is set to $10^{-3} \mathrm{~s}^{-1}$. As an additional sensitivity test, we implement the $k_{\mathrm{gw}}$ parameterization developed by Zhang et al. (2015) in which $k_{\mathrm{gw}}$ increases as species' volatility decreases. Transport between the gas phase and the wall is represented by the balance equations

$$
\begin{aligned}
& \left(\frac{\mathrm{d} G_{i}}{\mathrm{~d} t}\right)_{\mathrm{gw}}=-k_{\mathrm{gw}} G_{i}+k_{\mathrm{wg}} W_{i}, \\
& \left(\frac{\mathrm{d} W_{i}}{\mathrm{~d} t}\right)_{\mathrm{wg}}=k_{\mathrm{gw}} G_{i}-k_{\mathrm{wg}} W_{i},
\end{aligned}
$$

where $k_{\mathrm{gw}}$ and $k_{\mathrm{wg}}$ are first-order rate constants for transport to and from the wall, and $W_{i}$ is the concentration in the wall layer. The reverse rate is calculated assuming gas-wall partitioning follows Raoult's law (La et al., 2016):

$$
\frac{k_{\mathrm{gw}}}{k_{\mathrm{wg}}}=\frac{R T}{P^{\mathrm{vap}}} \frac{C_{\mathrm{w}}}{M_{\mathrm{w}} \gamma_{\mathrm{w}}},
$$


where $C_{\mathrm{w}}$ is the equivalent overall organic mass concentration in the wall, $M_{\mathrm{w}}$ is the equivalent molar weight of the organic concentration in the wall, and $\gamma_{\mathrm{w}}$ is the activity coefficient in the Teflon film. Values of $C_{\mathrm{w}} / M_{\mathrm{w}} \gamma_{\mathrm{w}}$ must be determined experimentally from chamber observations (Matsunaga and Ziemann, 2010; Zhang et al., 2015). In the present simulations, a nominal $C_{\mathrm{w}} / M_{\mathrm{w}} \gamma_{\mathrm{w}}$ value of $120 \mu \mathrm{mol} \mathrm{m}^{-3}$, the value determined by Matsunaga and Ziemann (2010) for 2-ketones, is used for all species except for $\alpha$-pinene, for which $C_{\mathrm{w}} / M_{\mathrm{w}} \gamma_{\mathrm{w}}=20 \mu \mathrm{mol} \mathrm{m}^{-3}$, the value determined by Matsunaga and Ziemann (2010) for alkenes. $C_{\mathrm{w}} / M_{\mathrm{w}} \gamma_{\mathrm{w}}$ is varied as a sensitivity test.

\section{Experimental}

Six $\alpha$-pinene photooxidation experiments were conducted in the Caltech dual $24 \mathrm{~m}^{3}$ environmental chambers at $\sim 298 \mathrm{~K}$ and $<5 \%$ RH (Table 1). Prior to each experiment, the Teflon chambers were flushed with purified, dry air for $24 \mathrm{~h}$ until the particle number concentration was $<10 \mathrm{~cm}^{-3}$ and volume concentration was $<0.01 \mu \mathrm{m}^{3} \mathrm{~cm}^{-3}$. Hydrogen peroxide $\left(\mathrm{H}_{2} \mathrm{O}_{2}\right)$ was used as the $\mathrm{OH}$ source by evaporating $113 \mu \mathrm{L}$ of $50 \mathrm{wt} \%$ aqueous solution into the chamber with $5 \mathrm{~L} \mathrm{~min}^{-1}$ purified air for $110 \mathrm{~min}$, resulting in an approximate starting $\mathrm{H}_{2} \mathrm{O}_{2}$ mixing ratio of $2 \mathrm{ppm}$. Experiments were conducted at low $\mathrm{NO}(<2 \mathrm{ppb})$. Heated $5 \mathrm{~L} \mathrm{~min}^{-1}$ of purified, dry air was flowed through a glass bulb containing liquid $\alpha$ pinene into the chamber for $30 \mathrm{~min}$, introducing $\sim 50 \mathrm{ppb}$ $\alpha$-pinene into the chamber. Ammonium sulfate (AS) seed aerosol was injected into the chamber by atomizing 0.015 or $0.1 \mathrm{M}$ aqueous $\left(\mathrm{NH}_{4}\right)_{2} \mathrm{SO}_{4}$ solution into the chamber for 30 to $90 \mathrm{~min}$, varying the initial AS concentration in order to vary the seed surface area (SA) available for condensation. After $\sim 1 \mathrm{~h}$ of mixing, photooxidation was initiated. Four of the experiments were performed using the full set of blacklights, for which the calculated $j_{\mathrm{NO}_{2}}=4 \times 10^{-3} \mathrm{~s}^{-1}$, with varying amounts of inorganic seed particles (Table 1). The remaining two experiments were performed using only $10 \%$ of the available blacklights, for which the calculated $j_{\mathrm{NO}_{2}}=3.7 \times 10^{-4} \mathrm{~s}^{-1}$, again with varying amounts of inorganic seed particles.

Relative humidity (RH) and temperature were monitored via a Vaisala HMM211 probe. $\mathrm{O}_{3}$ and $\mathrm{NO}_{x}$ mixing ratios were measured by a Horiba $\mathrm{O}_{3}$ analyzer (APOA-360) and a Teledyne $\mathrm{NO}_{x}$ analyzer (T200), respectively. $\alpha$-Pinene concentration was monitored by a gas chromatograph equipped with a HP-5 column $(15 \mathrm{~m} \times 0.53 \mathrm{~mm}$ ID $\times 1.5 \mu \mathrm{m}$ thickness, Hewlett-Packard) coupled with flame ionization detector (GC/FID, Agilent 6890N). The size distribution and number concentration of seed particles and organic aerosols were characterized using a custom-built Scanning Mobility Particle Sizer (SMPS) consisting of a Differential Mobility Analyzer (DMA, TSI, 3081) coupled with a Condensation Particle Counter (CPC, TSI, 3010).
Measured volume distributions must be corrected for particle wall loss; the DMA measures the total volume of particles, which is a mixture of organic aerosol and inorganic seed. By accounting for particle wall loss, the seed volume can be subtracted and the mass of SOA calculated. Two limiting assumptions have traditionally been made when correcting for particle wall loss (Loza et al., 2014): in the lower bound, once deposited, particles are assumed to no longer interact with the vapor. The mass of SOA present on a particle at the moment of its deposition is added when calculating the total SOA. In the upper bound, deposited particles are assumed to continue growing at the same rate as suspended particles, and this SOA is similarly added to the total SOA. The upper bound can be viewed as an early approximation of vapor wall loss from a time when vapor wall loss was less well understood. However, this approximation does not account for the differing mechanisms of vaporparticle and vapor-wall transport, which is reflected in different timescales. Moreover, the absorbing mass of the wall, represented by the parameter $C_{\mathrm{w}}$, is $\sim 3$ orders of magnitude higher than the mass of deposited particles (Zhang et al., 2014). The upper bound is therefore less appropriate to use when vapor wall loss is accounted for separately, and thus the lower bound is used to correct the SOA data, using size-dependent wall loss rates measured in the Caltech chamber. Figure S2 shows temporal plots of the experimental non-particle-wall-loss-corrected total volume and the total volume with both the upper and lower bound particle wall loss correction. (Gaps in the volume data resulted when the DMA was taken off-line briefly to clean the inlet.)

The initial concentrations of $\mathrm{H}_{2} \mathrm{O}_{2}, \mathrm{NO}_{x}$, and $\mathrm{O}_{3}$ in the chemical model were optimized to match the $\alpha$-pinene decay and $\mathrm{O}_{3}$ formation. The initial mixing ratio of $\mathrm{H}_{2} \mathrm{O}_{2}$ was optimized to be $2 \mathrm{ppm}$, yielding predicted $\mathrm{OH}$ levels of $\sim 2 \times 10^{6} \mathrm{molec} \mathrm{cm}^{-3}$ for the $100 \% \mathrm{UV}$ experiments and $\sim 2 \times 10^{5}$ molec $^{-3}$ for the $10 \%$ UV experiments. Although experiments were conducted under low-NO conditions, background levels of $\mathrm{NO}_{x}$ were observed in the chamber. Due to voltage interference in the $\mathrm{NO}_{x}$ measurements at such low values, it was not possible to determine the exact amount of $\mathrm{NO}_{x}$ present in the chamber. Therefore, the initial background concentration in the simulations was set to $0.1 \mathrm{ppb}$, split evenly between $\mathrm{NO}$ and $\mathrm{NO}_{2}$. $\mathrm{NO}$ and $\mathrm{NO}_{2}$ then evolve throughout the simulation according to the standard inorganic gas-phase reactions. Ozone formation was observed during the experiments, giving evidence of the presence of $\mathrm{NO}_{2}$ in the chamber. Because any $\mathrm{NO}_{2}$ initially present in the chamber is quickly photolyzed, a $\mathrm{NO}_{x}$ wall offgassing rate of $2.5 \mathrm{ppt} \mathrm{min}^{-1}$ is needed to match the observed ozone formation (e.g., Valorso et al., 2011). Predicted SOA formation is not sensitive to the assumed $\mathrm{NO}_{x}$ off-gassing rate. An initial $\mathrm{O}_{3}$ concentration was measured in the chamber; however, this was attributed to interference by $\mathrm{H}_{2} \mathrm{O}_{2}$ because $\alpha$-pinene did not decay in the dark, as would have occurred in the presence of $\mathrm{O}_{3}$. Therefore, the initial $\mathrm{O}_{3}$ was 
Table 1. Initial conditions for photooxidation experiments.

\begin{tabular}{llrrrrr}
\hline Expt. & Desc. & $T(\mathrm{~K})$ & $\mathrm{RH}(\%)$ & $\begin{array}{r}\mathrm{HC}_{0} \\
(\mathrm{ppb})\end{array}$ & $\begin{array}{r}\text { Initial seed surface } \\
\mathrm{Area}\left(\mu \mathrm{m}^{2} \mathrm{~cm}^{-3}\right)\end{array}$ & $\begin{array}{r}\text { Duration } \\
(\mathrm{min})\end{array}$ \\
\hline 141007 & Nucleation & 300 & $<5 \%$ & 51 & 0 & 300 \\
141016 & Low SA & 300 & $<5 \%$ & 56 & $1.7 \times 10^{3}$ & 534 \\
141028 & Med. SA & 300 & $<5 \%$ & 53 & $3.2 \times 10^{3}$ & 233 \\
141118 & High SA & 298 & $<5 \%$ & 51 & $3.4 \times 10^{3}$ & 410 \\
\hline 141113 & 10\% UV, low SA & 297 & $<5 \%$ & 53 & $9.9 \times 10^{2}$ & 1070 \\
141125 & $10 \%$ UV, med. SA & 297 & $<5 \%$ & 49 & $2.4 \times 10^{3}$ & 1160 \\
\hline
\end{tabular}

set to zero in the model. Comparisons of measurements and model predictions for the decay of $\alpha$-pinene and the evolution of $\mathrm{O}_{3}$ are shown in Figs. S3 and S4 in the Supplement.

Figure $\mathrm{S} 5$ shows the amount of $\alpha$-pinene predicted to react with $\mathrm{OH}$ vs. $\mathrm{O}_{3}$, using both the modeled and measured $\mathrm{O}_{3}$ concentration. For the $100 \%$ UV experiments, $\sim 2-3 \%$ of the total $\alpha$-pinene is predicted to react with $\mathrm{O}_{3}$, using either the modeled or measured $\mathrm{O}_{3}$ concentration. For the $10 \%$ UV experiments, $\sim 20 \%$ of the total $\alpha$-pinene is predicted to react with $\mathrm{O}_{3}$ using the modeled $\mathrm{O}_{3}$ concentration. For experiment 141113, roughly the same amount of $\alpha$-pinene is predicted to react with $\mathrm{O}_{3}$ based on the measured $\mathrm{O}_{3}$ concentration. However, for experiment 141125 , because the model underpredicts the $\mathrm{O}_{3}$ concentration, much more $\alpha$-pinene is predicted to react with the measured $\mathrm{O}_{3}$ concentration, $\sim 49 \%$.

\section{Results}

Experimental particle-wall-loss-corrected SOA growth curves as a function of reacted $\alpha$-pinene are shown in Fig. 2 for the six photooxidation experiments. With the exception of the nucleation experiment, SOA growth is observed immediately upon irradiation, similar to $\mathrm{Ng}$ et al. (2007a). When presented as a function of reacted $\alpha$-pinene, the growth curves essentially overlap, regardless of the UV level or the initial seed particle concentration. Overlap at two different UV intensities indicates that SOA growth is not very sensitive to the oxidation rate for these conditions. SOA yields (ratio of maximum mass of SOA formed to mass of $\alpha$-pinene reacted) for these experiments range from 17 to $26 \%$, at the low end of the range of previously reported yields of $26-45 \%$ for this system (Ng et al., 2007a; Eddingsaas et al., 2012b).

Figure 2 also shows predictions from the base GECKOA mechanism for the six experiments. In the GECKO-A model, the two main parameters representing vapor-particle and vapor-wall transport, $\alpha_{\mathrm{p}}$ and $k_{\mathrm{gw}}$, are set to nominal values of 1 and $10^{-3} \mathrm{~s}^{-1}$, respectively. $C_{\mathrm{w}} /\left(M_{\mathrm{w}} \gamma_{\mathrm{w}}\right)$ is set to $120 \mu \mathrm{mol} \mathrm{m}^{-3}$ for all species except $\alpha$-pinene. These parameters give a good agreement for the $100 \%$ UV experi-

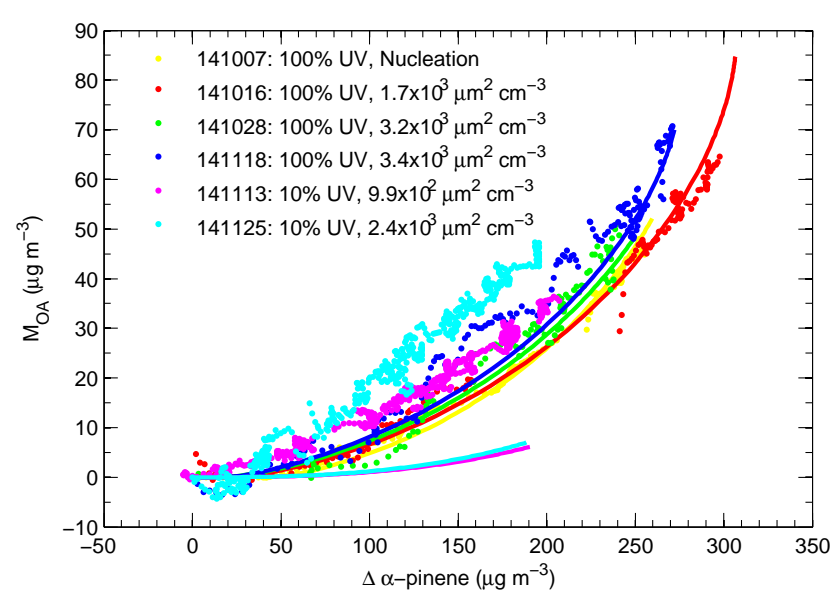

Figure 2. Mass of SOA, $M_{\mathrm{OA}}$, as a function of reacted $\alpha$-pinene. Experimental data are shown with filled circles, with colors corresponding to individual experiments (see Table 1), and have been corrected for particle wall loss (see text). Predictions using the default GECKO-A are shown as solid lines, with the colors corresponding to the different experiments. In GECKO-A, the vaporparticle accommodation coefficient is set to $\alpha_{\mathrm{p}}=1$, and the vapor wall loss rate is set to $k_{\mathrm{gw}}=10^{-3} \mathrm{~s}^{-1}$.

ments. Figure S6 in the Supplement shows the effect of varying the vapor-particle accommodation coefficient $\alpha_{\mathrm{p}}$ for different values of the vapor wall loss rate $k_{\mathrm{gw}} . \alpha_{\mathrm{p}}=1$ or 0.1 yields almost identical SOA predictions for all experiments except nucleation. In the nucleation case, $\alpha_{\mathrm{p}}=0.1$ results in substantially less SOA predicted, which may result because nucleation is not treated explicitly in GECKO-A but instead approximated by initializing the particle concentration with particles of $5 \mathrm{~nm}$ radius. Lowering the value of $\alpha_{\mathrm{p}}$ to 0.01 or 0.001 delays the onset of SOA formation for the $100 \%$ UV experiments, which is not consistent with experimental observations. Lowering $k_{\mathrm{gw}}$ results in substantial overprediction of SOA for the $100 \%$ UV experiments. For the $10 \%$ UV experiments, all combinations of parameters underpredict the SOA. Figure S7 in the Supplement shows the effect of varying $C_{\mathrm{w}} /\left(M_{\mathrm{w}} \gamma_{\mathrm{w}}\right)$ for different values of the vapor wall loss rate $k_{\mathrm{gw}} . C_{\mathrm{w}} /\left(M_{\mathrm{w}} \gamma_{\mathrm{w}}\right)$ controls partitioning between the 
gas phase and the wall at equilibrium; therefore, variations in $C_{\mathrm{w}} /\left(M_{\mathrm{w}} \gamma_{\mathrm{w}}\right)$ have more of an effect on SOA predictions when using a faster wall loss rate because equilibrium is approached sooner. The base $C_{\mathrm{w}} /\left(M_{\mathrm{w}} \gamma_{\mathrm{w}}\right)$ and $k_{\mathrm{gw}}=10^{-3} \mathrm{~s}^{-1}$ give the best agreement for $100 \%$ UV experiments; however, SOA for the $10 \% \mathrm{UV}$ experiments is still underpredicted. This discrepancy will be addressed subsequently. All subsequent simulations are conducted with $\alpha_{\mathrm{p}}=1$ and the base $C_{\mathrm{w}} /\left(M_{\mathrm{w}} \gamma_{\mathrm{w}}\right)$.

The best-fit $\alpha_{\mathrm{p}}=1$ (and 0.1 for all experiments except nucleation) for the $100 \%$ UV experiments suggests that there are no substantial limitations to vapor-particle mass transfer (Mai et al., 2015). This conclusion is consistent with the experimental observation that the SOA growth in this system is virtually independent of the amount of seed surface area present; dependence of SOA growth on seed surface area occurs only with diffusion- or accommodation-limited vaporparticle mass transfer (McVay et al., 2014). Optimal $\alpha_{\mathrm{p}}=1$ or 0.1 is consistent with Saleh et al. (2013), who determined accommodation coefficients of order 0.1 for $\alpha$-pinene ozonolysis SOA. This result differs from that of Zhang et al. (2014), who observed toluene SOA formation to depend strongly on the seed surface area and consequently to adhere to a low $\alpha_{\mathrm{p}}=0.001$. The different behavior observed for $\alpha$ pinene and toluene SOA may reflect differences in SOA formation mechanisms; however, it is not possible to discern the reason for the difference based solely on the data at hand. If $\alpha$-pinene SOA behaves as a semi-solid (Perraud et al., 2012; Cappa and Wilson, 2011; Vaden et al., 2010, 2013; Virtanen et al., 2010, 2011; Kuwata and Martin, 2012; Saukko et al., 2012; Abramson et al., 2013; Renbaum-Wolff et al., 2013), a lower $\alpha_{\mathrm{p}}$ might be expected. However, if, once formed, SOA is converted into a glassy state through hydrogen bonding or oligomerization (Cappa and Wilson, 2011), SOA formation itself could still be characterized by a high $\alpha_{\mathrm{p}}$.

The observation that SOA growth is insensitive to oxidation rate (shown by the overlap of the growth curves in Fig. 2 for different UV exposures) is not consistent with predictions regarding the interplay of reaction rate and vapor wall loss: if the reaction rate increases relative to the vapor wall loss rate, successive generations of low-volatility species will be produced more quickly and will condense preferentially onto particles before their precursors are lost to the chamber walls, leading to a higher SOA yield (Zhang et al., 2014; McVay et al., 2014). Such behavior was observed experimentally by $\mathrm{Ng}$ et al. (2007b): higher SOA yields were observed in the aromatic system using $\mathrm{HONO}$ as an $\mathrm{OH}$ precursor than when only $\mathrm{NO}$ and $\mathrm{NO}_{2}$ were present initially, leading to much lower OH levels. This "rate effect" was tentatively attributed by $\mathrm{Ng}$ et al. (2007b) to loss of semivolatile organics to the chamber walls, albeit at a time when the nature of vapor wall deposition was less well understood. A dependence of SOA growth on oxidation rate is also predicted by the base scenario in GECKO-A: the SOA levels are predicted to be substantially lower at $10 \%$ UV owing to significant organic mass loss to the walls. A number of explanations can be advanced for the overlap of the growth curves at high and low $\mathrm{UV}$, and these are systematically explored below.

\subsection{Negligible or slow vapor wall loss}

In the absence of vapor wall loss, the growth curves predicted by GECKO-A overlap at high and low UV (Fig. S8 in the Supplement). Oxidation occurs more slowly under low UV owing to the decreased rate of generation of $\mathrm{OH}$, but if condensable species or their precursors do not deposit on the walls, the same amount of SOA eventually forms. However, in the absence of vapor wall loss, GECKO-A overpredicts SOA substantially for the high-UV experiments and slightly for the low-UV experiments.

At a low level of vapor wall loss, $k_{\mathrm{gw}}=10^{-5} \mathrm{~s}^{-1}$, the growth curves predicted by GECKO-A still essentially overlap (Fig. 3). A rate effect, in which the SOA yield depends on the rate of oxidation, is observed only if the rate of oxidation is slower than or competitive with other loss processes. The rate constant for the reaction of $\mathrm{OH}$ with $\alpha$ pinene is $5.23 \times 10^{-11} \mathrm{~cm}^{3}$ molec $^{-1} \mathrm{~s}^{-1}$ (Atkinson and Arey, 2003). OH concentrations predicted by GECKO-A of $2 \times 10^{6}$ and $2 \times 10^{5} \mathrm{molec}^{-3}$ for the high- and low-UV experiments, respectively, give overall reaction rates of $10^{-4}$ and $10^{-5} \mathrm{~s}^{-1}$. (OH reaction rate constants for oxidized products will be slower than that for $\alpha$-pinene, and the reaction rate slows in later generations.) A vapor wall loss characterized by $k_{\mathrm{gw}}=10^{-3} \mathrm{~s}^{-1}$ exceeds substantially either of these reaction rates, and thus at this wall deposition rate the effect of changing oxidation rate is strong. At a much slower wall loss, $k_{\mathrm{gw}}=10^{-5} \mathrm{~s}^{-1}$, the rate effect is less pronounced, leading to overlap of the growth curves predicted by GECKO-A. The absence of a rate effect in the experimental observations is consistent with a slower vapor wall loss rate, in accord with wall loss rates that have been measured previously in the Caltech chamber (Loza et al., 2010, 2014; Zhang et al., 2015).

With a vapor wall loss rate of $10^{-5} \mathrm{~s}^{-1}$, SOA predictions match the data fairly well at low UV, within $10 \mu \mathrm{g} \mathrm{m}^{-3}$ of the final SOA concentration, but remain overpredicted by 80 to $200 \mathrm{\mu g} \mathrm{m}^{-3}$ at high UV. Thus, a slow wall loss rate alone is not sufficient to reconcile the predictions at high and low UV. However, it is instructive to examine the contribution of different generations of reaction to SOA predictions with this slow vapor wall loss (Fig. 4). GECKO-A predicts that SOA will consist of almost entirely second-generation products. At the end of the experiment, simulations under high UV predict $\sim 100 \mu \mathrm{g} \mathrm{m}^{-3}$ of second-generation products, as opposed to $\sim 50 \mu \mathrm{g} \mathrm{m}^{-3}$ for low UV. Thus, reducing the contribution of second-generation products in high UV may result in closer model-data agreement for both high- and low-UV conditions at a slow vapor wall loss rate. 


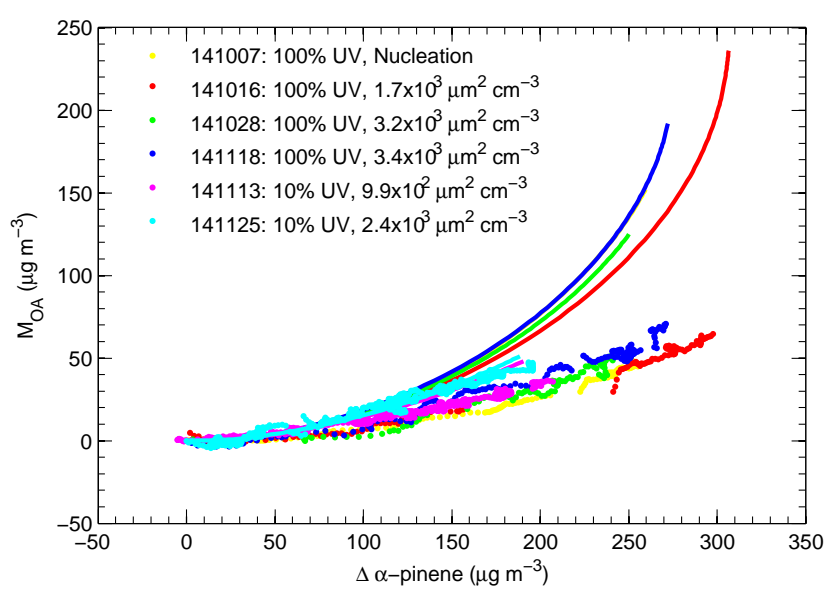

Figure 3. Mass of SOA as a function of reacted $\alpha$-pinene. Experimental data are shown as filled circles. Solid lines correspond to GECKO-A predictions using a vapor wall loss rate $k_{\mathrm{gw}}=$ $10^{-5} \mathrm{~s}^{-1}$.
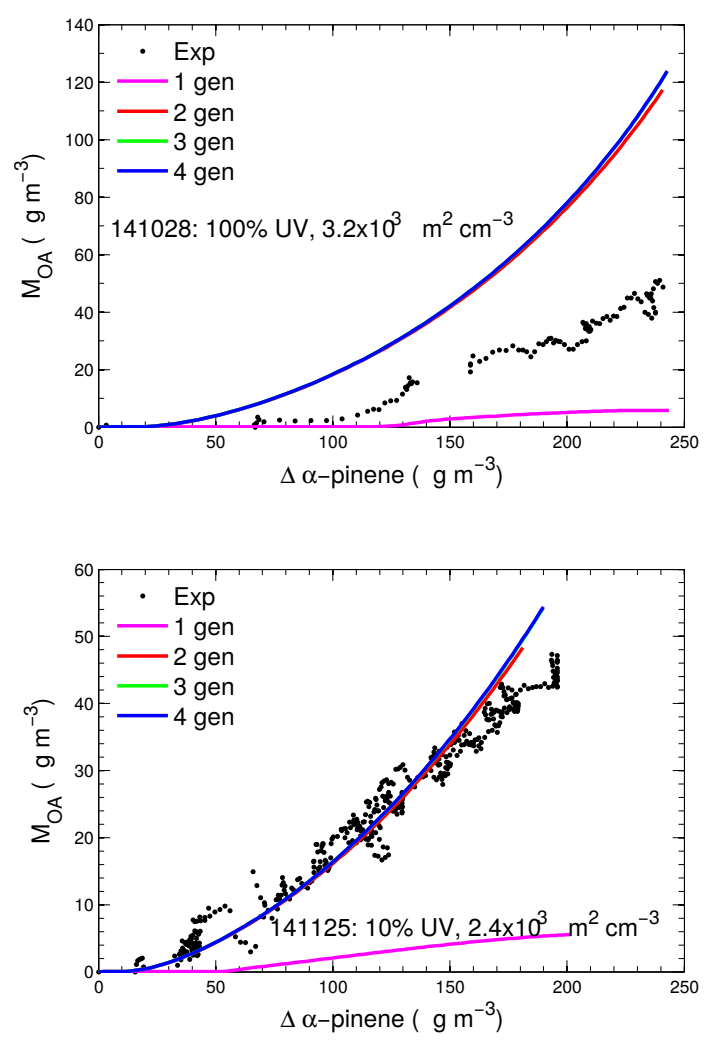

Figure 4. Mass of SOA as a function of reacted $\alpha$-pinene. Experimental data are shown with filled circles. Solid lines correspond to GECKO-A predictions from different generations of reaction using a vapor wall loss rate $k_{\mathrm{gw}}=10^{-5} \mathrm{~s}^{-1}$, where a generation corresponds to reaction with an oxidation such as $\mathrm{OH}$ up to formation of a stable product.

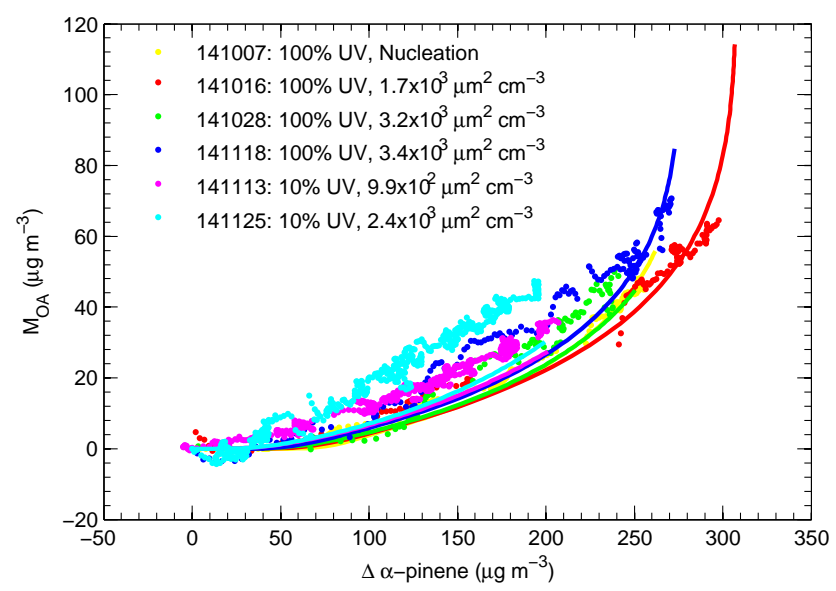

Figure 5. Mass of SOA as a function of reacted $\alpha$-pinene. Experimental data are shown with filled circles. Solid lines display GECKO-A predictions when using $\mathrm{OH}$ reaction rate constants that have been reduced to $10 \%$ of their default values (with the exception of $\alpha$-pinene $+\mathrm{OH})$ and $k_{\mathrm{gw}}=10^{-5} \mathrm{~s}^{-1}$.

\subsection{Overcontribution of second- and later-generation species}

As a sensitivity test, all $\mathrm{OH}$ reaction rate constants, except that of $\mathrm{OH}+\alpha$-pinene, are reduced by varying factors. Figure S9 in the Supplement shows the impact of reducing the $\mathrm{OH}$ rate constants to 1,10 , and $50 \%$ of the default values at a vapor wall loss rate of $10^{-5} \mathrm{~s}^{-1}$. A reduction to $10 \%$ and a wall loss rate of $10^{-5} \mathrm{~s}^{-1}$ result in the best fit to both highand low-UV experiments (Fig. 5), albeit with an overprediction up to $75 \%$ for the high-UV experiments and a $20-40 \%$ underprediction for the low-UV experiments. While this result does not necessarily suggest that reaction rate constants in GECKO-A are overpredicted by an order of magnitude, it does suggest that second- and higher-generation compounds may be primarily responsible for the model-measurement discrepancy at differing UV levels. An excess contribution of later-generation compounds to SOA in GECKO-A could be due to several factors: (1) overprediction of the $\mathrm{OH}$ reaction rate constants by the SARs, (2) assumed reaction pathways in GECKO-A, (3) underestimation of volatilities for latergeneration species, or (4) significantly faster wall loss rate for later-generation products. Each of these possibilities is considered in turn.

$\mathrm{OH}$ reaction rate constants in GECKO-A are based on SARs from Kwok and Atkinson (1995) and subsequent updates, which have been shown to predict $\mathrm{OH}$ reaction rate constants within a factor of 2 for alkanes, alkenes, and diols but may be more uncertain for the complex and highly functionalized compounds in later generations of $\alpha$-pinene oxidation (Bethel et al., 2001). For example, Bethel et al. (2001) showed that $\mathrm{OH}$ rate constants for 1,2-hydroxyaldehydes are overestimated by factors of 3-4 using the established SARs. 
Although rate constants are likely not overpredicted by an order of magnitude as the simulations suggest, it is possible that uncertainties in the SARs for later-generation species may contribute to the overprediction of these products by GECKO-A.

SARs used to predict reaction pathways and branching ratios in GECKO-A are also prone to uncertainties. In the reaction of peroxy radicals with $\mathrm{HO}_{2}$, the dominant pathway in GECKO-A is formation of the hydroperoxide (assumed branching ratio $80 \%$ ). $\alpha$-Pinene hydroxy dihydroperoxide $\left(\mathrm{C}_{10} \mathrm{H}_{16} \mathrm{O}_{5}\right)$ is a second-generation compound formed via two such reactions with $\mathrm{HO}_{2}$ that is predicted by GECKO-A to contribute significantly to SOA under the high-UV conditions. Figure S10 in the Supplement shows that eliminating the mass of this compound from SOA predictions in the absence of vapor wall loss results in a much more significant decrease in SOA at high UV $\left(\sim 100 \mu \mathrm{g} \mathrm{m}^{-3}\right)$ than at low UV $\left(\sim 15 \mu \mathrm{g} \mathrm{m}^{-3}\right)$. $\alpha$-Pinene hydroxy dihydroperoxide results from two successive $\mathrm{OH}$ reactions and is therefore formed more rapidly and in greater amounts at a higher $\mathrm{OH}$ level. $\alpha$-Pinene hydroxy dihydroperoxide has been observed in the gas phase with an estimated $3 \%$ yield (Eddingsaas et al., 2012a). In the high-UV simulation, this compound is formed with $>30 \%$ yield; therefore, it is likely that reaction pathways leading to this product are overrepresented in GECKO-A.

A second pathway for the reaction of peroxy radicals with $\mathrm{HO}_{2}$ is formation of an alkoxy and regeneration of $\mathrm{OH}$, added to GECKO-A with an uncertain branching ratio of $20 \%$ and only for peroxy radicals with an oxygenated moiety in the $\alpha$ position. Simulations show that SOA predictions are not sensitive to the second assumption but are very sensitive to the assumed branching ratio for this reaction (Fig. 6). Increasing formation of the alkoxy leads to decreasing SOA formation, with a greater effect at high UV than at low UV. Uncertainty in this branching ratio in the $\alpha$-pinene system could be a major factor leading to the high-low-UV discrepancy.

Finally, Praske et al. (2015) recently identified a third $\mathrm{HO}_{2}$ reaction channel for peroxy radicals produced from methyl vinyl ketone (MVK): formation of a carbonyl and regeneration of $\mathrm{OH}$ and $\mathrm{HO}_{2}$. In place of a hydroperoxide, which results from the standard $\mathrm{HO}_{2}$ reaction channel, this reaction produces a ketone which has a higher vapor pressure and therefore forms less SOA. If this reaction occurs in the $\alpha$-pinene system, the absence of this pathway in GECKO-A could contribute to SOA overprediction.

Volatilities in this version of GECKO-A are estimated using the Nannoolal et al. (2008) method, which is based on the Clausius-Clapeyron equation. Boiling points are estimated using the Nannoolal et al. $(2004,2008)$ method with some group contributions taken from Compernolle et al. (2010) (Valorso et al., 2011). Limited experimental data exist for vapor pressures of semivolatile and low-volatility species, and uncertainty in vapor pressure estimation increases as va-
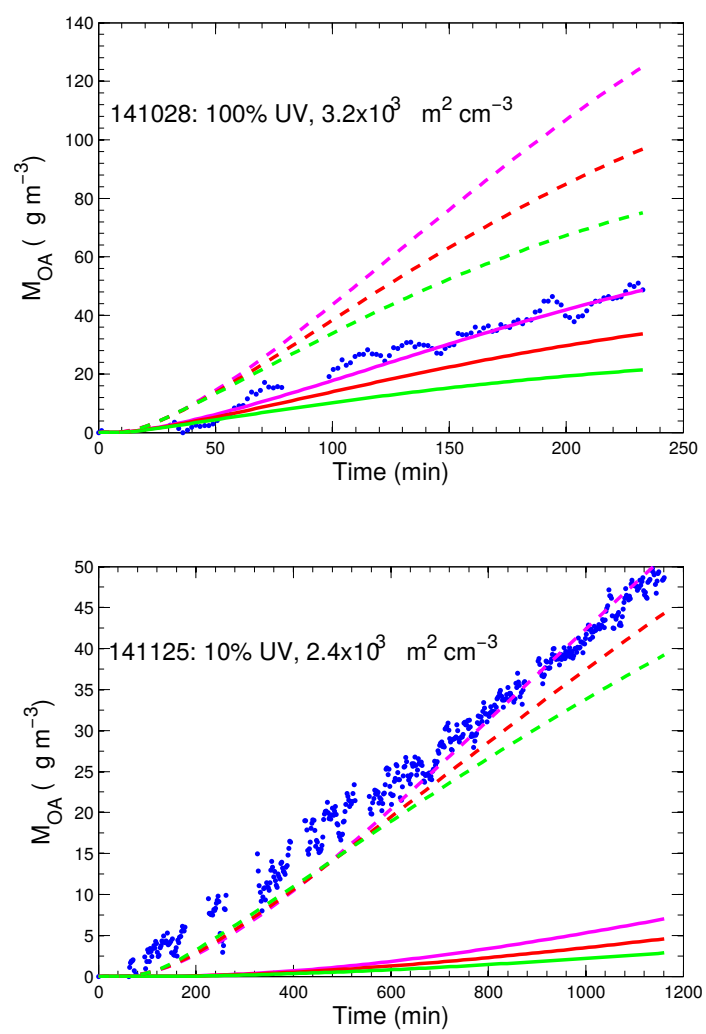

Figure 6. Mass of SOA as a function of time for one $100 \%$ UV and one $10 \%$ UV experiment. Experimental data are shown with filled circles. Lines show GECKO-A predictions when varying the branching ratio for the $\mathrm{RO}_{2}+\mathrm{HO}_{2}$ reaction with differing vapor wall loss rates. Solid lines show predictions with $k_{\mathrm{gw}}=10^{-3} \mathrm{~s}^{-1}$, and dashed lines show predictions with $k_{\mathrm{gw}}=10^{-5} \mathrm{~s}^{-1}$. Pink lines show the base case predictions, in which the branching between formation of the hydroperoxide and the alkoxy from $\mathrm{RO}_{2}+\mathrm{HO}_{2}$ is $80: 20$. For the red lines, the branching ratio is $50: 50$; for the green, it is $25: 75$.

por pressure decreases (Valorso et al., 2011). Therefore, underprediction of vapor pressures for later-generation species could lead to excess SOA. Indeed, Valorso et al. (2011) showed that significant uncertainties in SOA predictions result when using different methods for vapor pressure estimation. While the Nannoolal et al. (2008) method generally led to the highest volatilites and the lowest SOA predictions when compared to the Myrdal and Yalkowsky (1997) method and the SIMPOL-1 method from Pankow and Asher (2008), each of these methods estimates vapor pressures via a group contribution method (i.e., summing the contributions of all functional groups). If this approach is less accurate for compounds with many functional groups, the volatilities may be underpredicted and these species may be overpredicted in SOA.

A final possible explanation for the overprediction of higher-generation SOA species is that significantly faster vapor wall loss exists for these more functionalized species. 
Zhang et al. (2015) showed that vapor wall loss rates increase as compound vapor pressure decreases. They measured wall loss rates for primarily first-generation oxidation products to be $10^{-5}-10^{-6} \mathrm{~s}^{-1}$ in the Caltech chambers. Implementing the $k_{\mathrm{gw}}$ parameterization developed by Zhang et al. (2015) in GECKO-A yields similar SOA predictions to those based on assuming a fixed $k_{\mathrm{gw}}=10^{-5} \mathrm{~s}^{-1}$ (with the exception of the nucleation experiment, in which the $k_{\mathrm{gw}}$ parameterization predicted more SOA than using a fixed $k_{\mathrm{gw}}=10^{-5} \mathrm{~s}^{-1}$ ). However, it is certainly possible that later generation, more functionalized compounds could exhibit significantly faster wall loss than predicted by the parameterization of Zhang et al. (2015). As one example, Krechmer et al. (2015) fit a wall loss rate of $3 \times 10^{-3} \mathrm{~s}^{-1}$ for a $\mathrm{C}_{5} \mathrm{H}_{10} \mathrm{O}_{5}$ isoprene oxidation product in the Caltech chambers. If later-generation species in the $\alpha$-pinene system exhibit markedly higher wall loss as well, SOA overprediction in GECKO-A will be reduced.

In summary, if GECKO-A overpredicts the contribution of later-generation species, the measurement-model discrepancy at differing UV levels could be reduced. Reducing the contribution of second-generation species also requires a slower vapor wall loss rate to fit the data, which is actually more consistent with those that have been measured in the Caltech chamber.

\subsection{Condensed-phase photolysis}

If condensed-phase photolysis occurs in the chamber but is missing in GECKO-A, both the high-low-UV measurementmodel discrepancy and the high wall loss rate needed to match the $100 \%$ UV observations could potentially be explained. If condensed-phase photolysis is an efficient loss mechanism for SOA at $100 \% \mathrm{UV}$, a lower vapor wall loss rate would be required in order to continue to fit experimental observations. Because condensed-phase photolysis would be less efficient at $10 \% \mathrm{UV}$, at this slower wall loss rate the lowUV SOA predictions will increase in the direction of the observations. However, this effect is not seen in the simulations. Figure 7 shows the effect of condensed-phase photolysis, with the radicals produced assumed to be lost permanently. Two wall loss rates are shown: the default $k_{\mathrm{gw}}=10^{-3} \mathrm{~s}^{-1}$ and a slower $k_{\mathrm{gw}}=10^{-4} \mathrm{~s}^{-1}$. Only one high-UV experiment is shown, but the results are similar for all high-UV experiments. Moreover, condensed-phase photolysis has no effect on the low-UV predictions (not shown).

Under high-UV conditions, the assumed presence of condensed-phase photolysis leads to a slight reduction in SOA predictions at the end of the experiment, regardless of $k_{\mathrm{gw}}$. Note that the current implementation of condensedphase photolysis represents an upper limit: compounds in the condensed phase are taken to photolyze at the same rate as in the gas phase, and fragmentation products are lost permanently. The minor effect of this photolysis upper limit can be explained by comparing the wavelength-dependent photon flux of the chamber to absorption cross sections of species

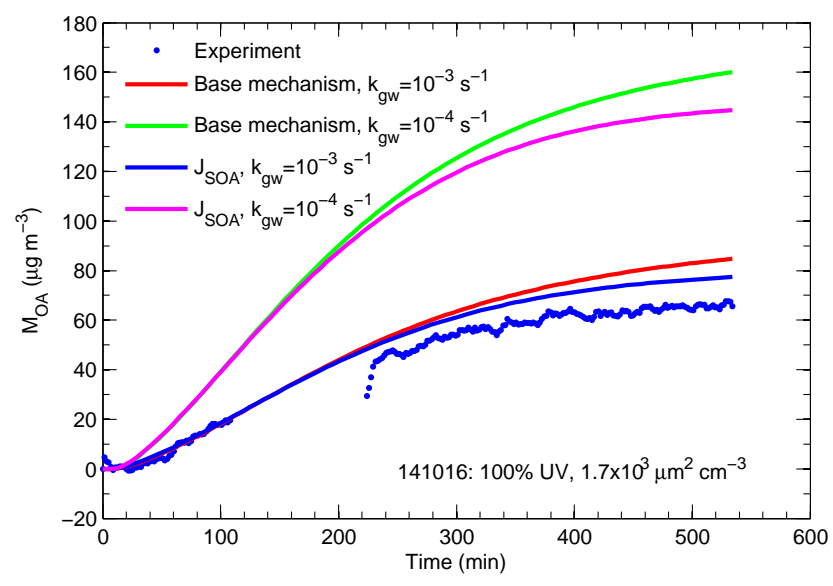

Figure 7. Mass of SOA as a function of time for one $100 \%$ UV experiment. Experimental data are shown with filled circles. Solid lines show GECKO-A predictions with and without condensedphase photolysis with two different vapor wall loss rates.

predicted to constitute the SOA (Fig. S11 in the Supplement). Wong et al. (2015) found that the main absorption region of SOA produced by $\alpha$-pinene ozonolysis corresponds to characteristic absorptions of carbonyl and peroxide functional groups and that the SOA absorption is strongest between 240 and $400 \mathrm{~nm}$. Although products of $\alpha$-pinene $\mathrm{OH}$ oxidation and ozonolysis differ, peroxide and carbonyl functional groups are generated during both (Eddingsaas et al., 2012a). The photon flux in the Caltech chamber is less intense than the solar flux in this region, particularly for the wavelength region over which peroxides photolyze (Fig. S11). Because peroxides are expected to be abundant in $\alpha$-pinene SOA (Capouet et al., 2008; Eddingsaas et al., 2012a), the effect of condensed-phase photolysis may be underrepresented in the Caltech chamber as compared to the atmosphere.

The minor effect of condensed-phase photolysis in these simulations is consistent with the findings of Hodzic et al. (2015) that reduction in SOA from both gas-phase and condensed-phase photolysis for various systems, including $\alpha$-pinene, is minor during the initial $10 \mathrm{~h}$ of a simulation but becomes substantial over a week of atmospheric ageing. Moreover, this result indicates that this process does not explain the high-low-UV measurement-model discrepancy. Even in the presence of condensed-phase photolysis, at a wall loss rate $k_{\mathrm{gw}}=10^{-4} \mathrm{~s}^{-1}$ a strong overprediction of SOA still exists at $100 \%$ UV. Although condensed-phase photolysis is potentially important in the atmosphere on longer timescales (Hodzic et al., 2015), it does not explain the lowUV measurement-model discrepancy of these experiments.

\subsection{Autoxidation chemistry}

Autoxidation has been demonstrated to be important in SOA formation (Crounse et al., 2013; Ehn et al., 2014; Rissanen et al., 2014; Jokinen et al., 2014; Mentel et al., 2015; Rissa- 
nen et al., 2015). Formation of extremely low-volatility organic compounds (ELVOCs) via autoxidation has been observed from both the $\mathrm{OH}$ oxidation and ozonolysis of $\alpha$ pinene, with higher yields observed from ozonolysis (Ehn et al., 2014; Jokinen et al., 2014). In autoxidation, a peroxy radical undergoes an intramolecular hydrogen abstraction to form a hydroperoxide, generating an alkyl radical which then adds oxygen to reform a peroxy radical. This pathway becomes important only when the rate of hydrogen abstraction is competitive with bimolecular reactions of the peroxy radicals with $\mathrm{NO}, \mathrm{HO}_{2}$, and $\mathrm{RO}_{2}$ (Crounse et al., 2013). Because lower UV intensities will lead to lower $\mathrm{HO}_{2}$ and $\mathrm{RO}_{2}$ concentrations, intramolecular hydrogen abstraction could potentially be favored under low UV. For the high-UV experiments, the predicted lifetime with $\mathrm{HO}_{2}$ is $\sim 10 \mathrm{~s}$; for the low$\mathrm{UV}$ experiments it is $\sim 50 \mathrm{~s}$, indicating that autoxidation may potentially be more important under low UV.

Moreover, during the low-UV experiments, $20-50 \%$ of $\alpha$ pinene reacts with $\mathrm{O}_{3}$ instead of $\mathrm{OH}$, compared to only 2$3 \%$ for the high-UV experiments. As discussed previously, the ozonolysis mechanism in GECKO-A is likely incomplete and may be lacking pathways to SOA precursors, such as autoxidation. Because autoxidation is much more efficient from the ozonolysis pathway than from the $\mathrm{OH}$ pathway (Ehn et al., 2014; Jokinen et al., 2014), more ELVOCs will likely be produced under low UV and will increase the amount of SOA formed. Furthermore, autoxidation could also explain the difference in SOA yield observed between the two lowUV experiments. Experiment 141125 has a higher yield than experiment 141113 and also has a higher observed $\mathrm{O}_{3}$ concentration. ELVOC production was likely higher during this experiment owing to the increased fraction of $\alpha$-pinene reacted via ozonolysis.

Autoxidation is observed to occur immediately upon oxidation (Rissanen et al., 2015), indicating that it is likely a first-generation process. Second-generation species are predominantly responsible for the discrepancy in model predictions between high and low UV due to the difference in $\mathrm{OH}$ levels (Fig. 4). Unlike second-generation products, autoxidation products will not depend on the $\mathrm{OH}$ concentration and will not be produced more slowly under low UV. Therefore, adding autoxidation pathways will likely increase the fraction of SOA composed of first-generation products, which may lead to similar predictions for high and low UV.

However, explicit mechanisms and rate constants are still lacking for autoxidation in the $\alpha$-pinene system, although they have been developed for simpler cycloalkenes (Mentel et al., 2015; Rissanen et al., 2015). A recent computational study found that the cyclobutyl ring in $\alpha$-pinene must open in order for intramolecular hydrogen shifts to be competitive with the peroxy bimolecular sink reactions (Kurtén et al., 2015). The currently accepted $\alpha$-pinene ozonolysis mechanism does not include rapid opening of this ring. Kurtén et al. (2015) investigated several pathways to break this ring but found none that could explain all of the characteristics of observed ELVOCs from $\alpha$-pinene. In the absence of explicit mechanisms, the effect of autoxidation cannot be fully tested. To approximate the effect, a $\mathrm{C}_{10} \mathrm{H}_{15} \mathrm{O}_{9}$ species (an ELVOC predicted by Kurtén et al., 2015) is added with a $7 \%$ molar yield (based on the 6-8 \% yield measured by Ehn et al., 2014) as a direct product from the $\alpha$-pinene $+\mathrm{O}_{3}$ reaction. This addition has no effect on SOA concentrations for the high-UV experiments but increases the final SOA concentrations for the low-UV experiments by $\sim 10 \mu \mathrm{g} \mathrm{m}^{-3}$ (not shown). However, adding this fixed ELVOC yield does not increase SOA predictions for low UV at the beginning of the experiment, when no $\mathrm{O}_{3}$ is present. Therefore, although autoxidation via ozonolysis is likely important towards the end of the low-UV experiments, other explanations are needed to reconcile the underprediction of SOA at the start of the experiment. Autoxidation via $\mathrm{OH}$ oxidation could potentially resolve part of this discrepancy, but no pathways or yields are yet available. Overall, autoxidation is a likely process to explain the measurement-model discrepancy at high and low UV but is in need of more study. The presence of significant autoxidation could furthermore lead to a different best-fit vapor wall loss rate.

\subsection{Particle-phase dimerization}

If dimerization is more competitive with gas-phase fragmentation at the lower $\mathrm{OH}$ levels at $10 \%$ lights, increased SOA growth could result. Figure 8 shows one $100 \%$ UV and one $10 \%$ UV experiment with two different values for the dimerization rate constant: $0.01 \mathrm{M}^{-1} \mathrm{~s}^{-1}$ (Ziemann and Atkinson, 2012; Capouet et al., 2008) and $12 \mathrm{M}^{-1} \mathrm{~s}^{-1}$ (Shiraiwa et al., 2013) using the same base $k_{\mathrm{gw}}=10^{-3} \mathrm{~s}^{-1}$. The $12 \mathrm{M}^{-1} \mathrm{~s}^{-1}$ rate constant results in significant SOA overprediction for both the $100 \%$ and the $10 \%$ UV experiments; the slower dimerization rate constant still results in an overprediction for the $100 \%$ UV experiment but an underprediction at $10 \%$ UV. For this rate constant, rapid vapor wall loss combined with the slower chemistry at low UV prevents significant SOA formation, despite dimerization. In the high-UV experiment, because gas-phase chemistry occurs faster relative to vapor wall loss, even a slower dimerization rate increases SOA predictions. While dimerization increases SOA predictions for low UV, it has the same effect at high UV. Therefore, dimerization in its current implementation in GECKOA does not resolve the low-UV discrepancy without causing an SOA overprediction for high UV.

\subsection{Enhanced wall loss at high UV}

To recapitulate, using the base chemistry in GECKO-A, predictions agree with the high-UV experiments when using a relatively fast vapor wall loss rate of $10^{-3} \mathrm{~s}^{-1}$, and predictions approximately match the low-UV experiments when using a much slower wall loss rate of $10^{-5} \mathrm{~s}^{-1}$. This result prompts the hypothesis that vapor wall loss could somehow 

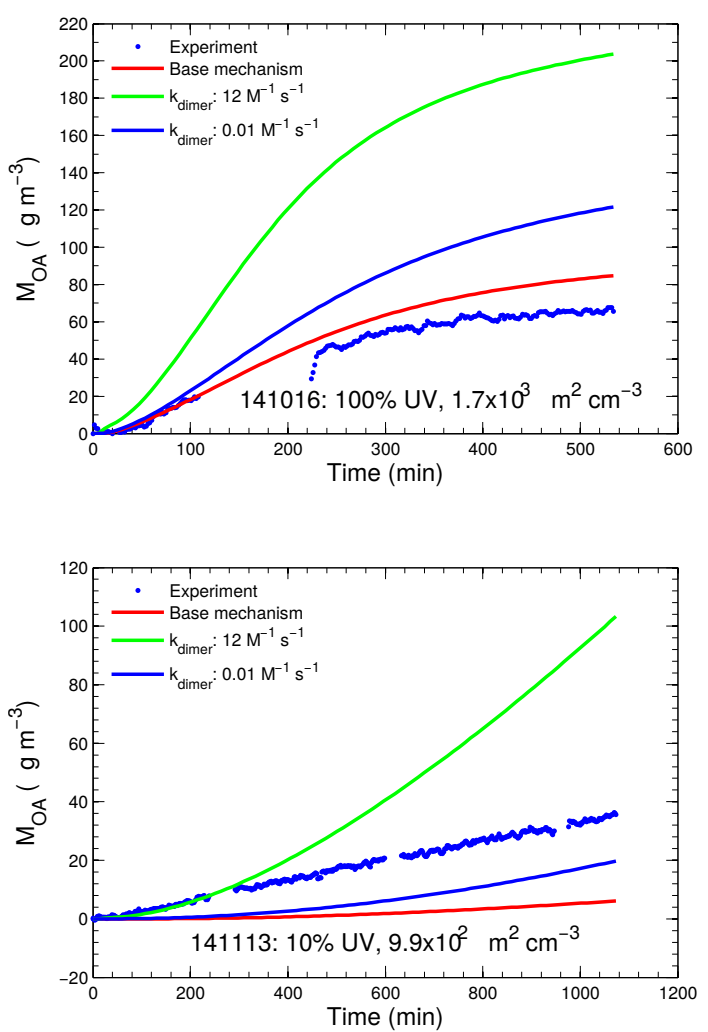

Figure 8. Mass of SOA as a function of time for one $100 \% \mathrm{UV}$ experiment and one $10 \%$ experiment. Experimental data are shown with filled circles. Solid lines show GECKO-A predictions for the base case and then with two values of a condensed-phase dimerization rate constant, with all simulations using $k_{\mathrm{gw}}=10^{-3} \mathrm{~s}^{-1}$.

be dependent on the UV level. The diffusion coefficient and the eddy diffusivity could change based solely on the UV level if a change in the UV level results in a temperature change in the chamber. The temperature of the chamber was $\sim 3 \mathrm{~K}$ higher for the high-UV experiments than for the low. Gas-phase diffusion coefficients are $\sim T^{3 / 2}$ (Incropera et al., 2007). A $3 \mathrm{~K}$ temperature increase will result in an increase in the diffusion coefficient by only a factor of 1.015. The eddy diffusivity characterizes the degree of turbulent mixing in the chamber, which could be increased by temperature variations. When UV lights are turned on, the temperature in the chamber increases by $2-3 \mathrm{~K}$ and then gradually decreases to the original temperature from a well-controlled recirculating chilled-water system. This small fluctuation is not expected to cause a dramatic increase in turbulence in the chamber. Therefore, increase of vapor wall loss for high-UV experiments is deemed incapable of explaining the modeling discrepancy.

\section{Atmospheric implications}

From the systematic analysis of the experiments and mechanism predictions (and in the absence of explicit autoxidation mechanisms), two hypotheses could explain some or all of the inability of the base case in GECKO-A to simulate both the high- and low-UV experiments. The first hypothesis is that later-generation species overcontribute to the SOA in GECKO-A. To compensate for this overcontribution necessitates the assumption of rapid vapor wall loss in order to fit the high-UV data; when extended to the low-UV experiments, this rapid wall loss results in significant SOA underprediction, since later-generation species are produced more slowly at the lower OH levels. This overcontribution could be the result of several possibilities, each of which has different implications for atmospheric SOA formation. If some reaction pathways are under- or misrepresented in GECKO-A, atmospheric predictions from GECKO-A may then overestimate SOA. If instead all reaction pathways in GECKO-A are realistic but the rates are simply overpredicted, these compounds may still form in the atmosphere but will be affected by competing processes such as dry and wet deposition and uptake into cloud particles (Hodzic et al., 2014; MouchelVallon et al., 2013). If volatilities are too low in GECKO-A, atmospheric predictions will then be biased high. Finally, if higher-generation species simply exhibit a faster wall loss, these compounds will be produced quickly in the atmosphere and will generate significant SOA.

This hypothesis implies that vapor wall loss in the Caltech chamber is likely slower than that of the base case assumed in GECKO-A. This slower wall loss is consistent with measurements in the Caltech chamber (Loza et al., 2010, 2014; Zhang et al., 2014) but is considerably slower than those measured in the $8 \mathrm{~m}^{3}$ chamber used by Yeh and Ziemann (2015), $10^{-3}$ $10^{-4} \mathrm{~s}^{-1}$. Differences in the size and operation of two chambers may contribute to the differences in measured wall loss rates.

The vapor wall loss implied by the present experiments results in an order of magnitude slower rate than that fit by Zhang et al. (2014) during toluene SOA photooxidation. This difference could potentially indicate differences between chemical systems or could also arise from the manner in which the modeling was performed: Zhang et al. (2014) used the Statistical Oxidation Model of Cappa and Wilson (2012) vs. the GECKO-A model used here. An implication of this difference is that the wall loss bias (the ratio of the yield predicted in the absence of vapor wall loss divided by the observed yield) for the $\alpha$-pinene system is likely lower than the 1.6 predicted by Zhang et al. (2014). However, because we could not definitively fit here both the high- and low-UV experiments, we cannot calculate a corresponding wall loss bias.

The second hypothesis with the potential to explain the measurement-model discrepancy is autoxidation. Autoxidation from both the $\mathrm{OH}$ and ozonolysis pathway could be 
important during the low-UV experiments. Explicit mechanisms and rate constants are needed in order to test this hypothesis. If significant, the presence of autoxidation could change the vapor wall loss rate implied by these simulations.

Although other processes do not reconcile the high-lowUV model discrepancy, such processes may still be important. Condensed-phase photolysis, though not significant over the short timescale of chamber experiments, has been shown to potentially have a more significant effect in the atmosphere (Hodzic et al., 2015). Particle-phase reactions have been shown to generate significant amounts of highmolecular weight, low-volatility species in the $\alpha$-pinene system (Docherty et al., 2005; Lopez-Hilfiker et al., 2015; Gao et al., 2004b), albeit more efficiently in ozonolysis (LopezHilfiker et al., 2015). Even if particle-phase dimerization is significant in this system, the assumed irreversible formation of dimers in GECKO-A may not accurately represent particle-phase reactions, which have been suggested to be reversible (Ziemann and Atkinson, 2012; Trump and Donahue, 2014).

\section{The Supplement related to this article is available online at doi:10.5194/acp-16-2785-2016-supplement.}

Acknowledgements. This work was supported by National Science Foundation grant AGS-1523500. Renee C. McVay acknowledges support by a National Science Foundation Graduate Research Fellowship under grant no. DGE-1144469. Bernard Aumont acknowledges support from the French National Research Agency (ANR) under the MAGNIFY project (ANR-14-CE01-0010).

Edited by: C. Hoyle

\section{References}

Abramson, E., Imre, D., Beránek, J., Wilson, J. M., and Zelenyuk, A.: Experimental determination of chemical diffusion within secondary organic aerosol particles, Phys. Chem. Chem. Phys., 15, 2983-2991, 2013.

Atkinson, R. and Arey, J.: Atmospheric degradation of volatile organic compounds, Chem. Rev., 103, 4605-4638, 2003.

Aumont, B., Szopa, S., and Madronich, S.: Modelling the evolution of organic carbon during its gas-phase tropospheric oxidation: development of an explicit model based on a self generating approach, Atmos. Chem. Phys., 5, 2497-2517, doi:10.5194/acp-52497-2005, 2005.

Bethel, H. L., Atkinson, R., and Arey, J.: Kinetics and products of the reactions of selected diols with the $\mathrm{OH}$ radical, Int. J. Chem. Kinet., 33, 310-316, 2001.

Bian, Q., May, A. A., Kreidenweis, S. M., and Pierce, J. R.: Investigation of particle and vapor wall-loss effects on controlled wood-smoke smog-chamber experiments, Atmos. Chem. Phys., 15, 11027-11045, doi:10.5194/acp-15-11027-2015, 2015.
Birdsall, A. W., Andreoni, J. F., and Elrod, M. J.: Investigation of the role of bicyclic peroxy radicals in the oxidation mechanism of toluene, J. Phys. Chem. A., 114, 10655-10663, 2010.

Camredon, M., Aumont, B., Lee-Taylor, J., and Madronich, S.: The SOA/VOC/NO ${ }_{x}$ system: an explicit model of secondary organic aerosol formation, Atmos. Chem. Phys., 7, 5599-5610, doi:10.5194/acp-7-5599-2007, 2007.

Cappa, C. D. and Wilson, K. R.: Evolution of organic aerosol mass spectra upon heating: implications for OA phase and partitioning behavior, Atmos. Chem. Phys., 11, 1895-1911, doi:10.5194/acp11-1895-2011, 2011.

Cappa, C. D. and Wilson, K. R.: Multi-generation gas-phase oxidation, equilibrium partitioning, and the formation and evolution of secondary organic aerosol, Atmos. Chem. Phys., 12, 9505-9528, doi:10.5194/acp-12-9505-2012, 2012.

Capouet, M., Peeters, J., Nozière, B., and Müller, J.-F.: Alphapinene oxidation by $\mathrm{OH}$ : simulations of laboratory experiments, Atmos. Chem. Phys., 4, 2285-2311, doi:10.5194/acp-4-22852004, 2004.

Capouet, M., Müller, J.-F., Ceulemans, K., Compernolle, S., Vereecken, L., and Peeters, J.: Modeling aerosol formation in alpha-pinene photo-oxidation experiments, J. Geophys. Res., 113, D02308, doi:10.1029/2007JD008995, 2008.

Claeys, M., Iinuma, Y., Szmigielski, R., Surratt, J. D., Blockhuys, F., Van Alsenoy, C., Boge, O., Siereau, B., GomezGonzalez, Y., Vermeylen, R., Van der Veken, P., Shahgholi, M., Chan, A. W. H., Herrmann, H., Seinfeld, J. H., and Maenhaut, W.: Terpenylic acid and related compounds from the oxidation of alpha-pinene: implications for new particle formation and growth above forests, Environ. Sci. Technol., 43, 6976-6982, 2009.

Compernolle, S., Ceulemans, K., and Müller, J.-F.: Technical Note: Vapor pressure estimation methods applied to secondary organic aerosol constituents from $\alpha$-pinene oxidation: an intercomparison study, Atmos. Chem. Phys., 10, 6271-6282, doi:10.5194/acp-10-6271-2010, 2010.

Crounse, J. D., Nielsen, L. B., Jørgensen, S., Kjaergaard, H. G., and Wennberg, P. O.: Autoxidation of organic compounds in the atmosphere, J. Phys. Chem. Lett., 4, 3513-3520, 2013.

Dillon, T. J. and Crowley, J. N.: Direct detection of $\mathrm{OH}$ formation in the reactions of $\mathrm{HO} 2$ with $\mathrm{CH}_{3} \mathrm{C}(\mathrm{O}) \mathrm{O}_{2}$ and other substituted peroxy radicals, Atmos. Chem. Phys., 8, 4877-4889, doi:10.5194/acp-8-4877-2008, 2008.

Docherty, K. S., Wu, W., Lim, Y. B., and Ziemann, P. J.: Contributions of organic peroxides to secondary aerosol formed from reactions of monoterpenes with $\mathrm{O}_{3}$, Environ. Sci. Technol., 39, 4049-4059, 2005.

Donahue, N. M., Henry, K. M., Mentel, T. F., Kiendler-Scharr, A., Spindler, C., Bohn, B., Brauer, T., Dorn, H. P., Fuchs, H., Tillmann, R., Wahner, A., Saathoff, H., Naumann, K. H., Möhler, O., Leisner, T., Müller, L., Reinnig, M. C., Hoffmann, T., Salo, K., Hallquist, M., Frosch, M., Bilde, M., Tritscher, T., Barmet, P., Praplan, A. P., DeCarlo, P. F., Dommen, J., Prévôt, A. S., and Baltensperger, U.: Aging of biogenic secondary organic aerosol via gas-phase $\mathrm{OH}$ radical reactions, P. Natl. Acad. Sci. USA, 21, 13503-13508, 2012.

Eddingsaas, N. C., Loza, C. L., Yee, L. D., Seinfeld, J. H., and Wennberg, P. O.: $\alpha$-pinene photooxidation under controlled chemical conditions - Part 1: Gas-phase composition in low- and 
high-NO $\mathrm{N}_{x}$ environments, Atmos. Chem. Phys., 12, 6489-6504, doi:10.5194/acp-12-6489-2012, 2012a.

Eddingsaas, N. C., Loza, C. L., Yee, L. D., Chan, M., Schilling, K. A., Chhabra, P. S., Seinfeld, J. H., and Wennberg, P. O.: $\alpha$-pinene photooxidation under controlled chemical conditions - Part 2: SOA yield and composition in low- and high- $\mathrm{NO}_{x}$ environments, Atmos. Chem. Phys., 12, 7413-7427, doi:10.5194/acp-12-74132012, 2012b.

Ehn, M., Thornton, J. A., Kleist, E., Sipilä, M., Junninen, H., Pullinen, I., Springer, M., Rubach, F., Tillmann, R., Lee, B., Lopez-Hilfiker, F., Andres, S., Acir, I.-H., Rissanen, M., Jokinen, T., Schobesberger, S., Kangasluoma, J., Kontkanen, J., Nieminen, T., Kurtén, T., Nielsen, L. B., Jørgensen, S., Kjaergaard, H. G., Canagaratna, M., Maso, M. D., Berndt, T., Petäjä, T., Wahner, A., Kerminen, V.-M. Kulmala, M., Worsnop, D. R., Wildt, J., and Mentel, T. F.: A large source of low-volatility secondary organic aerosol, Nature, 506, 476-479, doi:10.1038/nature13032, 2014.

Epstein, S. A., Blair, S. L., and Nizkorodov, S. A.: Direct photolysis of $\alpha$-pinene ozonolysis secondary organic aerosol: Effect on particle mass and peroxide content, Environ. Sci. Technol., 48, 11251-11258, 2014.

Fahnestock, K. A. S., Yee, L. D., Loza, C. L., Coggon, M. M., Schwantes, R., Zhang, X., Dalleska, N. F., and Seinfeld, J. H.: Secondary organic aerosol composition from $\mathrm{C}_{12}$ alkanes, $\mathrm{J}$. Phys. Chem. A., 119, 4281-4297, 2014.

Gao, S., Ng, N. L., Keywood, M., Varutbangkul, V., Bahreini, R., Nenes, A., He, J., Yoo, K. Y., Beauchamp, J. L., Hodyss, R. P., Flagan, R. C., and Seinfeld, J. H.: Particle phase acidity and oligomer formation in secondary organic aerosol, Environ. Sci. Technol., 38, 6582-6589, 2004a.

Gao, S., Keywood, M., Ng, N. L., Surratt, J., Varutbangkul, V., Bahreini, R., Flagan, R. C., and Seinfeld, J. H.: Low-molecularweight and oligomeric components in secondary organic aerosol from the ozonolysis of cycloalkenes and $\alpha$-pinene, J. Phys. Chem. A., 108, 10147-10164, 2004b.

Griffin, R. J., Cocker III, D. R., Flagan, R. C., and Seinfeld, J. H.: Organic aerosol formation from the oxidation of biogenic hydrocarbons. J. Geophys. Res., 104, 3555-3567, 1999.

Geunther, A., Hewitt, C. N., Erickson, D., Fall, R., Geron, C., Graedel, T., Harley, P., Klinger, L., Lerdau, M., Mckay, W. A., Pierce, T., Scholes, B., Seinbrecher, R., Tallamraju, R., Taylor, J., and Zimmerman, P.: A global model of natural volatile organic compound emissions, J. Geophys. Res., 100, 8873-8892, 1995.

Hallquist, M., Wenger, J. C., Baltensperger, U., Rudich, Y., Simpson, D., Claeys, M., Dommen, J., Donahue, N. M., George, C., Goldstein, A. H., Hamilton, J. F., Herrmann, H., Hoffmann, T., Iinuma, Y., Jang, M., Jenkin, M. E., Jimenez, J. L., Kiendler-Scharr, A., Maenhaut, W., McFiggans, G., Mentel, Th. F., Monod, A., Prévôt, A. S. H., Seinfeld, J. H., Surratt, J. D., Szmigielski, R., and Wildt, J.: The formation, properties and impact of secondary organic aerosol: current and emerging issues, Atmos. Chem. Phys., 9, 5155-5236, doi:10.5194/acp-9-51552009, 2009.

Hasson, A. S., Tyndall, G. S., and Orlando, J. J.: A product yield study of the reaction of $\mathrm{HO}_{2}$ radicals with ethyl peroxy $\left(\mathrm{C}_{2} \mathrm{H}_{5} \mathrm{O}_{2}\right)$, acetyl peroxy $\left(\mathrm{CH}_{3} \mathrm{C}(\mathrm{O}) \mathrm{O}_{2}\right)$, and acetonyl peroxy $\left(\mathrm{CH}_{3} \mathrm{C}(\mathrm{O}) \mathrm{CH}_{2} \mathrm{O}_{2}\right)$, J. Phys. Chem. A., 108, 5979-5989, 2004.
Hasson, A. S., Kuwata, K. T., Arroyo, M. C., and Petersen, E. B.: Theoretical studies of the reaction of hydroperoxy radicals $\left(\mathrm{HO}_{2}^{-}\right)$, with ethyl peroxy $\left(\mathrm{C}_{2} \mathrm{H}_{5} \mathrm{O}_{2}^{-}\right)$, acetyl peroxy $\left(\mathrm{CH}_{3} \mathrm{C}(\mathrm{O}) \mathrm{O}_{2}^{-}\right)$and acetonyl peroxy $\left(\mathrm{CH}_{3} \mathrm{C}(\mathrm{O}) \mathrm{CH}_{2} \mathrm{O}_{2}^{\circ}\right)$ radicals, J. Photoch. Photobio. A, 176, 218-230, 2005.

Henry, K. M. and Donahue, N. M.: Photochemical aging of $\alpha$ pinene secondary organic aerosol: Effects of $\mathrm{OH}$ radical sources and photolysis, J. Phys. Chem. A., 116, 5932-5940, 2012.

Hodzic, A., Aumont, B., Knote, C., Lee-Taylor, J., Madronich, S., and Tyndall, G.: Volatility dependence of Henry's law constants of condensable organics: application to estimate depositional loss of secondary organic aerosol, Geophys. Res. Lett., 41, 47954804, 2014.

Hodzic, A., Madronich, S., Kasibhatla, P. S., Tyndall, G., Aumont, B., Jimenez, J. L., Lee-Taylor, J., and Orlando, J.: Organic photolysis reactions in tropospheric aerosols: effect on secondary organic aerosol formation and lifetime, Atmos. Chem. Phys., 15, 9253-9269, doi:10.5194/acp-15-9253-2015, 2015.

Hoffmann, T., Odum, J. R., Bowman, F., Collins, D., Klockow, D., Flagan, R. C., and Seinfeld, J. H.: Formation of organic aerosols from the oxidation of biogenic hydrocarbons, J. Atmos. Chem., 26, 189-222, 1997.

Incropera, F. P., Dewitt, D. P., Bergman, T. L., and Lavine, A. S.: Fundamentals of Heat and Mass Transfer, 6th Edn., Wiley, Hoboken, NJ, 2007.

Jimenez, J. L., Canagaratna, M. R., Donahue, N. M., Prévôt, A. S., Zhang, Q., Kroll, J. H., DeCarlo, P. F., Allan, J. D., Coe, H., Ng, N. L., Aiken, A. C., Docherty, K. S., Ulbrich, I. M., Grieshop, A. P., Robinson, A. L., Duplissy, J., Smith, J. D., Wilson, K. R., Lanz, V. A., Hueglin, C., Sun, Y. L., Tian, J., Laaksonen, A., Raatikainen, T., Rautiainen, J., Vaattovaara, P., Ehn, M., Kulmala, M., Tomlinson, J. M., Collins, D. R., Cubison, M. J., Dunlea, E. J., Huffman, J. A., Onasch, T. B., Alfarra, M. R., Williams, P. I., Bower, K., Kondo, Y., Schneider, J., Drewnick, F., Borrmann, S., Weimer, S., Demerjian, K., Salcedo, D., Cottrell, L., Griffin, R., Takami, A., Miyoshi, T., Hatakeyama, S., Shimono, A., Sun, J. Y., Zhang, Y. M., Dzepina, K., Kimmel, J. R., Sueper, D., Jayne, J. T., Herndon, S. C., Trimborn, A. M., Williams, L. R., Wood, E. C., Middlebrook, A. M., Kolb, C. E., Baltensperger, U., and Worsnop, D. R.: Evolution of organic aerosols in the atmosphere, Science, 326, 1525-1529, 2009.

Jokinen, T., Sipilä, M., Richters, S., Kerminen, V.-M., Paasonen, P., Stratmann, F., Worsnop, D., Kulmala, M., Ehn, M., Herrmann, H., and Berndt, T.: Rapid autoxidation forms highly oxidized $\mathrm{RO}_{2}$ radicals in the atmosphere, Angew. Chem. Int. Edit., 53, 14596-14600, 2014.

Kalberer, M., Paulsen, D., Sax, M., Steinbacher, M., Dommen, J., Prévôt, A. S. H., Fisseha, R., Weingartner, E., Frankevich, V., Zenobi, R., and Baltensperger, U.: Identification of polymers as major components of atmospheric organic aerosols, Science, 303, 1659-1662, 2004.

Kamens, R. and Jaoui, M.: Modeling aerosol formation from $\alpha$ pinene $+\mathrm{NO}_{x}$ in the presence of natural sunlight using gas-phase kinetics and gas-particle partitioning theory, Environ. Sci. Technol., 35, 1394-1405, 2001.

Kokkola, H., Yli-Pirilä, P., Vesterinen, M., Korhonen, H., Keskinen, H., Romakkaniemi, S., Hao, L., Kortelainen, A., Joutsensaari, J., Worsnop, D. R., Virtanen, A., and Lehtinen, K. E. J.: The role 
of low volatile organics on secondary organic aerosol formation, Atmos. Chem. Phys., 14, 1689-1700, doi:10.5194/acp-14-16892014, 2014.

Krechmer, J. E., Coggon, M. M., Massoli, P., Nguyen, T. B., Crounse, J. D., Hu, W., Day, D. A., Tyndall, G. S., Henze, D. V., Rivera-Rios, J. C., Nowak, J. B., Kimmel, J. R., Mauldin III, R. L., Stark, H., Jayne, J. T., Sipilä, M., Junninen, H., St. Clair, J. M., Zhang, X., Feiner, P. A., Zhang, L., Miller, D. O., Brune, W. H., Keutsch, F. N., Wennberg, P. O., Seinfeld, J. H., Worsnop, D. R., Jimenez, J. L., and Canagaratna, M. R.: Formation of low volatility organic compounds and secondary organic aerosol from isoprene hydroxyhydroperoxide low-NO oxidation, Environ. Sci. Technol., 49, 10330-10339, 2015.

Kurtén, T., Rissanen, M. P., Mackeprang, K., Thornton, J. A., Hyttinen, N., Jørgensen, S., Ehn, M., and Kjaergaard, H. G.: Computational study of hydrogen shifts and ring-opening mechanisms in $\alpha$-pinene ozonolysis products, J. Phys. Chem. A., 119, 1136611375, 2015.

Kuwata, M. and Martin, S. T.: Phase of atmospheric secondary organic material affects its reactivity, P. Natl. Acad. Sci. USA, 109, 17354-17359, 2012.

Kwok, E. S. C. and Atkinson, R.: Estimation of hydroxyl radical reaction rate constants for gas-phase organic compounds using a structure-reactivity relationship: an update, Atmos. Environ., 29, 1685-1695, 1995.

La, Y. S., Camredon, M., Ziemann, P. J., Valorso, R., Matsunaga, A., Lannuque, V., Lee-Taylor, J., Hodzic, A., Madronich, S., and Aumont, B.: Impact of chamber wall loss of gaseous organic compounds on secondary organic aerosol formation: explicit modeling of SOA formation from alkane and alkene oxidation, Atmos. Chem. Phys., 16, 1417-1431, doi:10.5194/acp-161417-2016, 2016.

Lee-Taylor, J., Hodzic, A., Madronich, S., Aumont, B., Camredon, M., and Valorso, R.: Multiday production of condensing organic aerosol mass in urban and forest outflow, Atmos. Chem. Phys., 15, 595-615, doi:10.5194/acp-15-595-2015, 2015.

Lopez-Hilfiker, F. D., Mohr, C., Ehn, M., Rubach, F., Kleist, E., Wildt, J., Mentel, Th. F., Carrasquillo, A. J., Daumit, K. E., Hunter, J. F., Kroll, J. H., Worsnop, D. R., and Thornton, J. A.: Phase partitioning and volatility of secondary organic aerosol components formed from $\alpha$-pinene ozonolysis and $\mathrm{OH}$ oxidation: the importance of accretion products and other low volatility compounds, Atmos. Chem. Phys., 15, 7765-7776, doi:10.5194/acp-15-7765-2015, 2015.

Loza, C. L., Chan, A. W., Galloway, M. M., Keutsch, F. N., Flagan, R. C., and Seinfeld, J. H.: Characterization of vapor wall loss in laboratory chambers, Environ. Sci. Technol., 44, 50745078, 2010.

Loza, C. L., Craven, J. S., Yee, L. D., Coggon, M. M., Schwantes, R. H., Shiraiwa, M., Zhang, X., Schilling, K. A., Ng, N. L., Canagaratna, M. R., Ziemann, P. J., Flagan, R. C., and Seinfeld, J. H.: Secondary organic aerosol yields of 12-carbon alkanes, Atmos. Chem. Phys., 14, 1423-1439, doi:10.5194/acp-14-14232014, 2014.

Ma, Y., Russell, A. T., and Marston, G.: Mechanisms for the formation of secondary organic aerosol components from the gasphase ozonolysis of $\alpha$-pinene, Phys. Chem. Chem. Phys., 10, 4294-4312, 2008.
Mai, H., Shiraiwa, M., Flagan, R. C., and Seinfeld, J. H.: Under what conditions can equilibrium gas-particle partitioning be expected to hold in the atmosphere?, Environ. Sci. Technol., 49, 11485-11491, 2015.

Matsunaga, A. and Ziemann, P. J.: Gas-wall partitioning of organic compounds in a teflon film chamber and potential effects on reaction product and aerosol yield measurements, Aerosol Sci. Tech., 44, 881-892, 2010.

McVay, R. C., Cappa, C. D., and Seinfeld, J. H.: Vapor-wall deposition in chambers: theoretical considerations, Environ. Sci. Technol., 48, 10251-10258, 2014.

Mentel, T. F., Springer, M., Ehn, M., Kleist, E., Pullinen, I., Kurtén, T., Rissanen, M., Wahner, A., and Wildt, J.: Formation of highly oxidized multifunctional compounds: autoxidation of peroxy radicals formed in the ozonolysis of alkenes - deduced from structure-product relationships, Atmos. Chem. Phys., 15, 67456765, doi:10.5194/acp-15-6745-2015, 2015.

Mouchel-Vallon, C., Bräuer, P., Camredon, M., Valorso, R., Madronich, S., Herrmann, H., and Aumont, B.: Explicit modeling of volatile organic compounds partitioning in the atmospheric aqueous phase, Atmos. Chem. Phys., 13, 1023-1037, doi:10.5194/acp-13-1023-2013, 2013.

Myrdal, P. B. and Yalkowsky, S. H.: Estimating pure component vapor pressures of complex organic molecules, Ind. Eng. Chem. Res., 36, 2494-2499, 1997.

Nannoolal, Y., Rarey, J., Ramjugernath, D., and Cordes, W.: Estimation of pure component properties: Part 1. Estimation of the normal boiling point of non-electrolyte organic compounds via group contributions and group interactions, Fluid Phase Equilibr., 226, 45-63, 2004.

Nannoolal, Y., Rarey, J., and Ramjugernath, D.: Estimation of pure component properties: Part 3: Estimation of the vapor pressure of non-electrolyte organic compounds via group contribution and group interactions, Fluid Phase Equilibr., 269, 117-133, 2008.

Ng, N. L., Kroll, J. H., Keywood, M. D., Bahreini, R., Varutbangkul, V., Flagan, R. C., Seinfeld, J. H., Lee, A., and Goldstein, A. H.: Contribution of first- versus second-generation products to secondary organic aerosols formed in the oxidation of biogenic hydrocarbons, Environ. Sci. Technol., 40, 2283-2297, 2006.

Ng, N. L., Chhabra, P. S., Chan, A. W. H., Surratt, J. D., Kroll, J. H., Kwan, A. J., McCabe, D. C., Wennberg, P. O., Sorooshian, A., Murphy, S. M., Dalleska, N. F., Flagan, R. C., and Seinfeld, J. H.: Effect of NOx level on secondary organic aerosol (SOA) formation from the photooxidation of terpenes, Atmos. Chem. Phys., 7, 5159-5174, doi:10.5194/acp-7-5159-2007, 2007a.

Ng, N. L., Kroll, J. H., Chan, A. W. H., Chhabra, P. S., Flagan, R. C., and Seinfeld, J. H.: Secondary organic aerosol formation from $m$-xylene, toluene, and benzene, Atmos. Chem. Phys., 7, 3909-3922, doi:10.5194/acp-7-3909-2007, 2007b.

Nozière, B., Barnes, I., and Becker, K. H.: Product study and mechanisms of the reactions of $\alpha$-pinene and of pinonaldehyde with OH radicals, J. Geophys. Res., 104, 645-656, 1999.

Pankow, J. F. and Asher, W. E.: SIMPOL.1: a simple group contribution method for predicting vapor pressures and enthalpies of vaporization of multifunctional organic compounds, Atmos. Chem. Phys., 8, 2773-2796, doi:10.5194/acp-8-27732008, 2008. 
Pathak, R. K., Stanier, C. O., Donahue, N. M., and Pandis, S. N.: Ozonolysis of $\alpha$-pinene at atmospherically relevant concentrations: Temperature dependence of aerosol mass fractions (yields), J. Geophys. Res., 112, D03201, doi:10.1029/2006JD007436, 2007.

Peeters, J., Vereecken, L., and Fantechi, G.: The detailed mechanism of the $\mathrm{OH}$-initiated atmospheric oxidation of $\alpha$-pinene: A theoretical study, Phys. Chem. Chem. Phys., 3, 5489-5504, 2001.

Perraud, V., Bruns, E. A., Ezell, M. J., Johnson, S. N., Yu, Y., Alexander, M. L., Zelenyuk, A., Imre, D., Chang, W. L., Dabdub, D., Pankow, J., and Finlayson-Pitts, B. J.: Nonequilibrium atmospheric secondary organic aerosol formation and growth, $\mathrm{P}$. Natl. Acad. Sci. USA, 109, 2836-2841, 2012.

Praske, E., Crounse, J. D., Bates, K. H., Kurtén, T., Kjaergaard, H. G., and Wennberg, P. O.: Atmospheric fate of methyl vinyl ketone: peroxy radical reactions with $\mathrm{NO}$ and $\mathrm{HO}_{2}$, J. Phys. Chem., 119, 4562-4572, 2015.

Presto, A. A., Huff Hartz, K. E., and Donahue, N. M.: Secondary organic aerosol production from terpene ozonolysis: 1. Effect of UV radiation, Environ. Sci. Technol., 39, 7036-7045, 2005a.

Presto, A. A., Huff Hartz, K. E., and Donahue, N. M.: Secondary organic aerosol production from terpene ozonolysis: 2. Effect of $\mathrm{NO}_{x}$ concentration, Environ. Sci. Technol., 39, 7046-7054, 2005b.

Pye, H. O. T., Chan, A. W. H., Barkley, M. P., and Seinfeld, J. H.: Global modeling of organic aerosol: the importance of reactive nitrogen $\left(\mathrm{NO}_{x}\right.$ and $\left.\mathrm{NO}_{3}\right)$, Atmos. Chem. Phys., 10, 1126111276, doi:10.5194/acp-10-11261-2010, 2010.

Renbaum-Wolff, L., Grayson, J. W., Bateman, A. P., Kuwata, M., Sellier, M., Murray, B. M., Shilling, J. E., Martin, S. T., and Bertram, A. K.: Viscosity of $\alpha$-pinene secondary organic material and implications for particle growth and reactivity, P. Natl. Acad. Sci. USA, 110, 8014-8019, 2013.

Rissanen, M. P., Kurtén, T., Sipilä, M., Thornton, J. A., Kangasluoma, J., Sarnela, N., Junninen, H., Jørgensen, S., Schallhart, S., Kajos, M. K., Taipale, R., Springer, M., Mentel, T. F., Ruuskanen, T., Petäjä, T., Worsnop, D. R., Kjaergaard, H. G., and Ehn, M.: The formation of highly oxidized multifunctional products in the ozonolysis of cyclohexene, J. Am. Chem. Soc., 136, 15596-15606, 2014.

Rissanen, M. P., Kurtén, T., Sipilä, M., Thornton, J. A., Kausiala, O., Garmash, O., Kjaergaard, H. G., Petäjä, T., Worsnop, D. R., Ehn, M., and Kulmala, M.: Effects of chemical complexity on the autoxidation mechanisms of endocyclic alkene ozonolysis products: from methylcyclohexenes toward understanding $\alpha$ pinene, J. Phys. Chem., 119, 4633-4650, 2015.

Saleh, R., Donahue, N. M., and Robinson, A. L.: Time scales for gas-particle partitioning equilibration of secondary organic aerosol formed from alpha-pinene ozonolysis, Environ. Sci. Technol., 47, 5588-5594, 2013.

Saukko, E., Lambe, A. T., Massoli, P., Koop, T., Wright, J. P., Croasdale, D. R., Pedernera, D. A., Onasch, T. B., Laaksonen, A., Davidovits, P., Worsnop, D. R., and Virtanen, A.: Humiditydependent phase state of SOA particles from biogenic and anthropogenic precursors, Atmos. Chem. Phys., 12, 7517-7529, doi:10.5194/acp-12-7517-2012, 2012.

Seinfeld, J. H. and Pandis, S. N.: Atmospheric Chemistry and Physics: From Air Pollution to Climate Change, 2nd Edn. Wiley, Hoboken, N. J., 2006.
Shilling, J. E., Chen, Q., King, S. M., Rosenoern, T., Kroll, J. H., Worsnop, D. R., McKinney, K. A., and Martin, S. T.: Particle mass yield in secondary organic aerosol formed by the dark ozonolysis of a-pinene, Atmos. Chem. Phys., 8, 2073-2088, doi:10.5194/acp-8-2073-2008, 2008.

Shiraiwa, M., Yee, L. D., Schilling, K. A., Loza, C. L., Craven, J. S., Zuen, A., Ziemann, P. J., and Seinfeld, J. H.: Size distribution dynamics reveal particle-phase chemistry in organic aerosol formation, P. Natl. Acad. Sci. USA., 110, 11746-11750, 2013.

Takekawa, H., Minoura, H., and Yamazaki, S.: Temperature dependence of secondary organic aerosol formation by photo-oxidation of hydrocarbons, Atmos. Environ., 37, 3413-3424, 2003.

Tobias, H. J. and Ziemann, P. J.: Kinetics of the gas-phase reactions of alcohols, aldehydes, carboxylic acids, and water with the C13 stabilized Criegee intermediate formed from ozonolysis of 1-tetradecene, J. Phys. Chem. A., 105, 6129-6135, 2001.

Tolocka, M. P., Jang, M., Ginter, J. M., Cox, F. J., Kamens, R. M., and Johnston, M. V.: Formation of oligomers in secondary organic aerosol, Environ. Sci. Technol., 38, 1428-1434, 2004.

Trump, E. R. and Donahue, N. M: Oligomer formation within secondary organic aerosols: equilibrium and dynamic considerations, Atmos. Chem. Phys., 14, 3691-3701, doi:10.5194/acp-143691-2014, 2014.

Vaden, T. D., Song, C., Zaveri, R. A., Imre, D., and Zelenyuk, A.: Morphology of mixed primary and secondary organic particles and the adsorption of spectator organic gases during aerosol formation, P. Natl. Acad. Sci. USA, 107, 6658-6663, 2010.

Vaden, T. D., Imre, D., Beránek, J., Shrivastava, M., and Zelenyuk, A.: Evaporation kinetics and phase of laboratory and ambient secondary organic aerosol, P. Natl. Acad. Sci. USA, 108, 2190-2195, 2011.

Valorso, R., Aumont, B., Camredon, M., Raventos-Duran, T., Mouchel-Vallon, C., Ng, N. L., Seinfeld, J. H., Lee-Taylor, J., and Madronich, S.: Explicit modelling of SOA formation from apinene photooxidation: sensitivity to vapour pressure estimation, Atmos. Chem. Phys., 11, 6895-6910, doi:10.5194/acp-11-68952011, 2011.

Vereecken, L., Müller, J.-F., and Peeters, J.: Low-volatility polyoxygenates in the $\mathrm{OH}$-initiated atmospheric degradation of alpha-pinene: impact of non-traditional peroxy radical chemistry, Phys. Chem. Chem. Phys., 9, 5241-5248, 2007.

Virtanen, A., Joutsensaari, J., Koop, T., Kannosto, J., Yli-Pirilä, P., Leskinen, J., Mäkelä, J. M., Holopainen, J. K., Pöschl, U., Kulmala, M., Worsnop, D. R., and Laaksonen, A.: An amorphous solid state of biogenic secondary organic aerosol particles, Nature, 467, 824-827, 2010.

Virtanen, A., Kannosto, J., Kuuluvainen, H., Arffman, A., Joutsensaari, J., Saukko, E., Hao, L., Yli-Pirilä, P., Tiitta, P., Holopainen, J. K., Keskinen, J., Worsnop, D. R., Smith, J. N., and Laaksonen, A.: Bounce behavior of freshly nucleated biogenic secondary organic aerosol particles, Atmos. Chem. Phys., 11, 8759-8766, doi:10.5194/acp-11-8759-2011, 2011.

Wong, J. P. S., Zhou, S., and Abbatt, P. D.: Changes in secondary organic aerosol composition and mass due to photolysis: relative humidity dependence, J. Phys. Chem. A., 119, 4309-4316, 2015.

Yee, L. D., Craven, J. S., Loza, C. L., Schilling, K. A., Ng, N. L., Canagaratna, M. R., Ziemann, P. J., Flagan, R. C., and Seinfeld, J. H.: Effect of chemical structure on secondary organic aerosol 
formation from $\mathrm{C}_{12}$ alkanes, Atmos. Chem. Phys., 13, 1112111140, doi:10.5194/acp-13-11121-2013, 2013.

Yeh, G. K. and Ziemann, P. J.: Alkyl nitrate formation from the reactions of $\mathrm{C}_{8}-\mathrm{C}_{14} n$-alkanes with $\mathrm{OH}$ radicals in the presence of $\mathrm{NO}_{x}$ : measured yields with essential corrections for gas-wall partitioning, J. Phys. Chem. A., 118, 8147-8157, 2014.

Yeh, G. K. and Ziemann, P. J.: Gas-wall partitioning of oxygenated organic compounds: measurements, structure-activity relationships, and correlation with gas chromatographic retention factor, Aerosol. Sci. Tech., 49, 727-738, 2015.

Zhang, X., Cappa, C. D., Jathar, S. H., McVay, R. C., Ensberg, J. J., Kleeman, M. J., and Seinfeld, J. H.: Influence of vapor wall-loss in laboratory chambers on yields of secondary organic aerosol, P. Natl. Acad. Sci. USA, 111, 5802-5807, doi:10.1073/pnas.1404727111, 2014.
Zhang, X., Schwantes, R. H., McVay, R. C., Lignell, H., Coggon, M. M., Flagan, R. C., and Seinfeld, J. H.: Vapor wall deposition in Teflon chambers, Atmos. Chem. Phys., 15, 4197-4214, doi:10.5194/acp-15-4197-2015, 2015.

Ziemann, P. J. and Atkinson, R.: Kinetics, products, and mechanisms of secondary organic aerosol formation, Chem. Soc. Rev., 41, 6582-6605, 2012. 